
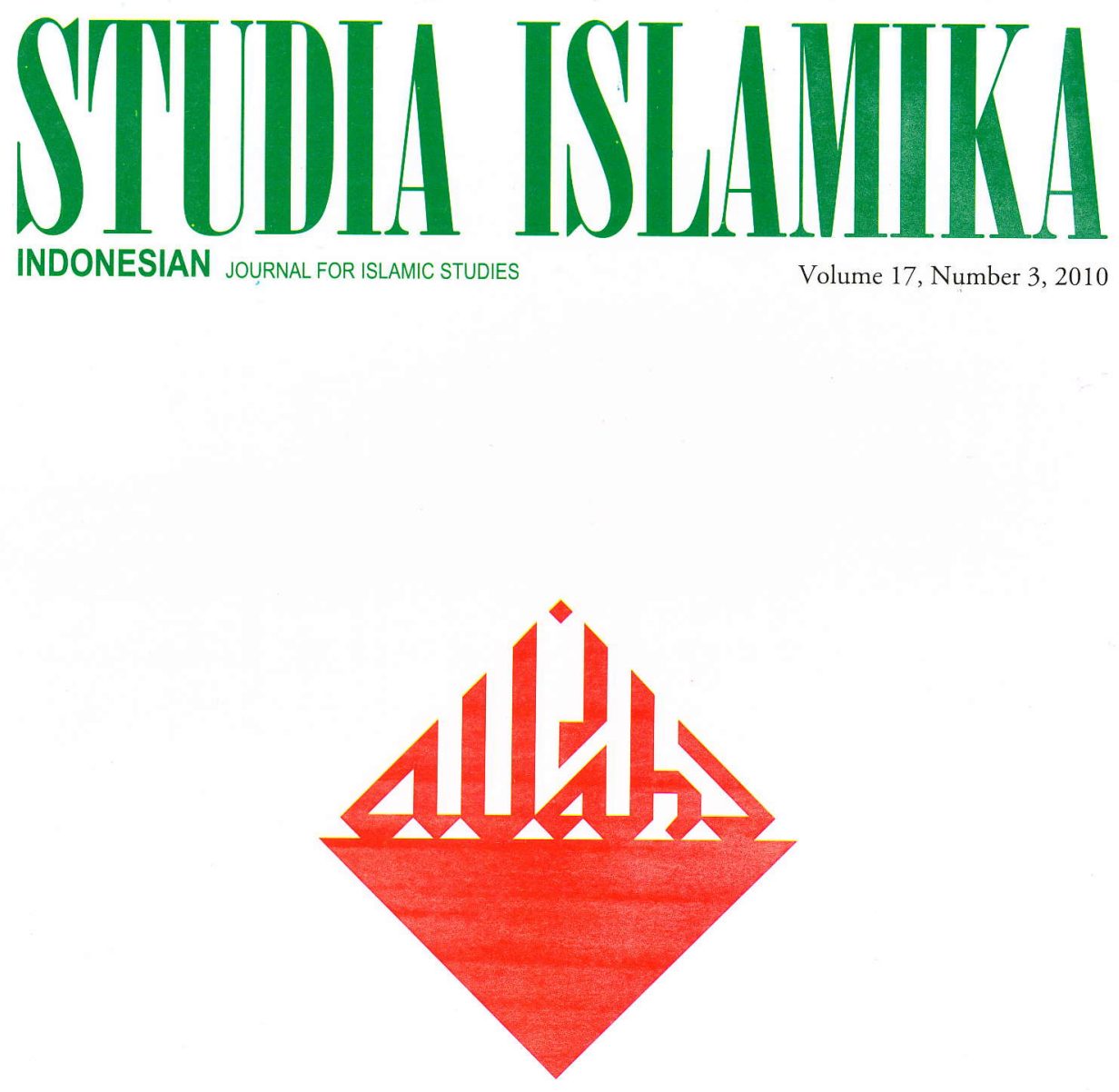

THE ELITIST PREMISES OF

SnOUCK Hurgonje'S Association Fantasy

Kees van Dijk

The Shaving of The Prophet's Hair (NABI APARAS):

The Philology of Lombok TeXts

Dick van der Meij

RELIGION AND DIALOGUE IN INDONESIA:

From the SOEHARTO PERIOD TO THE PRESENT

Mujiburrahman 


\section{EDITORIAL BOARD:}

M. Quraish Shihab (UIN Jakarta)

Taufik Abdullah (LIPI Jakarta)

Nur A. Fadhil Lubis (IAIN Sumatra Utara)

M.C. Ricklefs (National University of Singapore)

Martin van Bruinessen (Utrecht University)

John R. Bowen (Washington University, St. Louis)

M. Atho Mudzhar (UIN Jakarta)

M. Kamal Hasan (International Islamic University, Kuala Lumpur)

M. Bary Hooker (Australian National University, Australia)

Virginia Matheson Hooker (Australian National University, Australia)

\section{EDITOR-IN-CHIEF}

Azpumardi Azra

\section{EDITORS}

Jajat Burbanudin

Saiful Mujani

Jambari

Fu'ad Jabali

Oman Fathurabman

\section{ASSISTANT TO THE EDITORS}

\section{Testriono}

Setyadi Sulaiman

\section{ENGLISH LANGUAGE ADVISOR}

Dina Afrianty

Dick van der Meij

\section{ARABIC LANGUAGE ADVISOR}

Abmadi Rojali

\section{COVER DESIGNER}

\section{S. Prinka}

STUDIA ISLAMIKA (ISSN 0215-0492) is a journal published by the Center for the Study of Islam and Society (PPIM) UIN Syarif Hidayatullah, Jakarta (STT DEPPEN No. 129/SKIDITJEN/PPG/STT/1976). It specializes in Indonesian Islamic studies in particular, and South-east Asian Islamic Studies in general, and is intended to communicate original researches and current issues on the subject. This journal warmly welcomes contributions from scholars of related disciplines.

All articles published do not necessarily represent the views of the journal, or other institutions to which it is affliated. They are solely the views of the authors. The articles contained in this journal have been refereed by the Board of Editors. 


\title{
Dick van der Meij
}

\section{The Shaving of the Prophet's Hair (Nabi Aparas): The Philology of Lombok Texts}

\begin{abstract}
Abstrak: Teks Islam dari pulau Lombok jarang diedit dan diterjemahkan. Padahal, di pulau ini jumlah naskah sangat banyak. Lebih penting lagi, teks Islam dari Lombok menyediakan informasi penting tentang bagaimana Islam dipahami oleh masyarakat Sasak, dan peran yang mungkin dimainkan oleh tradisi teks dalam mentransmisikan perspektif lokal dan supralokal mengenai dua ragam Islam: waktu telu dan waktu lima di pulau Lombok. Aspek-aspek lain dari tradisi teks berbasis manuskrip dari Lombok juga masih belum memperoleh perhatian memadai. Alasannya adalah karena memang manuskrip Islam dari pulau tersebut belum banyak diedit dan diterjemahkan.

Produksi manuskrip di Lombok sangat besar dan terdapat ribuan. Namun, para filolog masih mengabaikan tradisi teks ini dan hanya beberapa edisi teks yang telah dikaji. Beragam teks dalam manuskrip dari Lombok memang membutuhkan penerapan banyak metode dan pendekatan filologis tradisional, serta melahirkan ketidakpastian metodologis. Selain itu, tradisi filologi mengehendaki bahwa semua atau paling tidak sebanyak mungkin naskah diteliti sebelum suatu teks diedit. Situasi inilah yang terjadi dalam studi manuskrip di Lombok. Persoalan apakah memang naskah dikopi di Lombok atau apakah semua naskah memang merupakan ciptaan sang pengkopi/penyalin/pengarang sendiri, tidak pernah diajukan kepada manuskripmanuskrip yang tersedia

Naskah Nabi Aparas memiliki banyak variasi. Banyaknya variasi manuskrip boleh jadi baik di dalam batas-batas yang diharapkan. Artikel ini melihat perbedaan di antara tiga naskah lontar kecil (ditandai dengan $A, B$, dan C) berisi mengenai Nabi Aparas (Nabi Bercukur). Naskah ini menggunakan bahasa Jawa dan ditulis dalam huruf jejawen, yaitu bentuk lokal dari aksara Jawa yang digunakan di Lombok. Oleh masyarakat lokal, manuskrip ini dianggap sebagai jimat atau memiliki kekuatan magis untuk melindungi diri melawan bahaya seperti sakit, pencurian, kebakaran,
\end{abstract}

441 Studia Islamika, Vol. 17, No. 3, 2010 
banjir, roh jahat, dan kecelakaan dalam perjalanan. Naskah ini cukup kecil sehingga dapat dibawa kemanapun dan kapanpun, dan penjelasan luas tentang faidah teks ditambahkan sebelum dan setelah cerita mengenai bercukur. Manuskrip tidak memberi informasi apapun mengenai penulis, pengkopi, waktu penulisan, atau dari bagian Lombok mana naskah itu berasal—sebagaimana umumnya manuskrip dari wilayah Lombok, dan tidak ada kolofon yang tersedia.

Artikel ini melihat perbedaan yang ditemukan di antara teks yang tercantum dalam ketiga naskah Nabi Aparas pada tingkat: 1) bahasa, 2) jenis sajak dan bagaimana jenisnya ditandakan, 3) kosakata, 4) urutan kalimat, 5) ulangan, 6) penghilangan, 7) perbedaan isi cerita, dan 8) kesalahan yang nyata. Terdapat banyak kesesuaian antara naskah $A$ dan $B$ ketika dibandingkan dengan $C$. Kesesuaian antara $A-C$ atau $B-C$ juga ada, tapi jarang. Banyaknya perbedaan yang ditemukan merupakan indikasi kalau bukan bukti bahwa tradisi kopi-mengopi naskah di Lombok tidak ada ataupun tidak seketat sebagaimana di daerah lain di Nusantara. Teks ketiga naskah dihadirkan supaya pembaca bisa membandingkannya.

Perbedaan antara tiga naskah yang dibahas terutama ditemukan dalam penggunaan kosa kata. Dari eksposisi nama-nama Allah yang digunakan dalam naskah, dan dari tabel panjang kata kerja dapat disimpulkan bahwa variasi leksikal antara manuskrip yang melimpah, namun saat mengganti teks, mereka tidak mengganggu atau mengubah cerita. Arti yang sama kurang lebih terdapat dalam kata-kata yang berbeda. Kenyataan bahwa kata-kata yang ditemukan dalam satu naskah tampaknya berubah secara acak untuk sinonim dalam naskah-naskah lain, ditambah dengan frekuensi perbedaan yang tinggi itu, menunjukkan bahwa kata demi kata proses menggandakan transmisi mungkin tidak disyaratkan. Karena fenomena ini umum terjadi, maka bisa disimpulkan bahwa ini adalah praktek standar dalam transmisi teks tertulis di daerah Lombok. Gagasan utamanya yang disampaikan, dan dengan demikian, melestarikan cerita dan bukan teks naskah tertentu atau tradisi naskah.

Karena kurangnya kolofon, dan karena belum ada penelitian mendalam yang dilakukan mengenai keunikan ortografi manuskrip dari Lombok, maka sulit untuk menentukan kapan manuskrip ditulis, dan tidak mungkin menjelaskan sebab historis dari proses transmisi manuskrip. Memutuskan untuk mengedit manuskrip tertua karenanya tidak mungkin sebagaimana sulitnya memutuskan yang mana manuskrip yang tertua. Untuk saat ini, yang paling penting adalah mengedit teks-teks terpanjang karena itu berisi setidaknya banyak informasi. Sementara pengkajian terhadap ceritacerita dalam teks tersebut tetap merupakan upaya lanjutan yang menjadi tugas para filolog berikutnya. 


\section{Dick van der Meij}

The Shaving of the Prophet's Hair (Nabi Aparas): The Philology of Lombok Texts

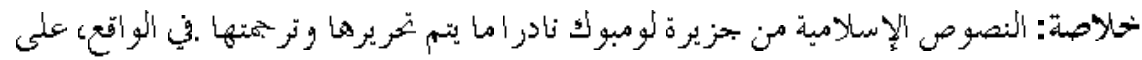

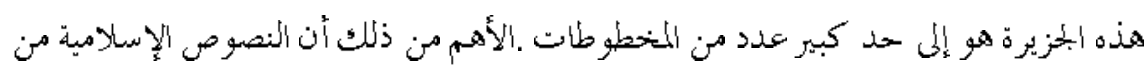

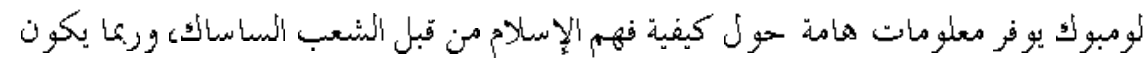

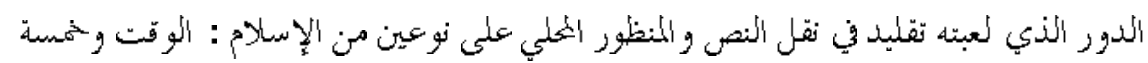

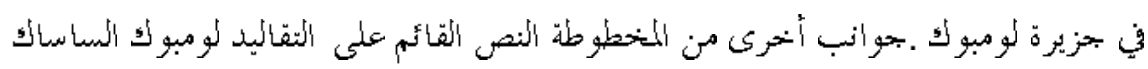

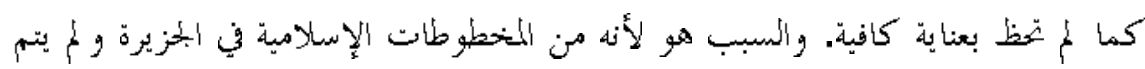
تحر بره و تر مجنده.

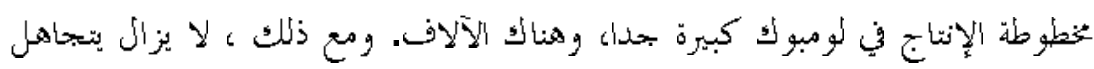

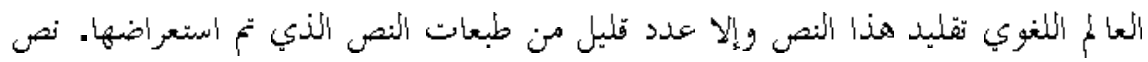

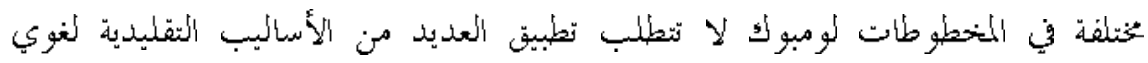

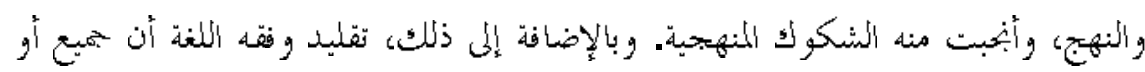

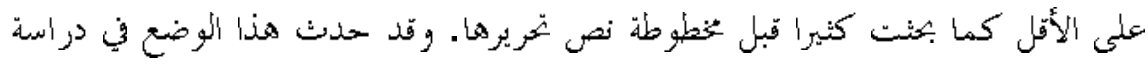

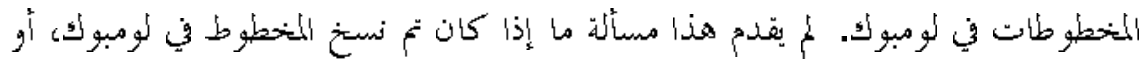

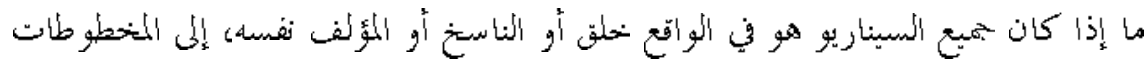
المئا ححة.

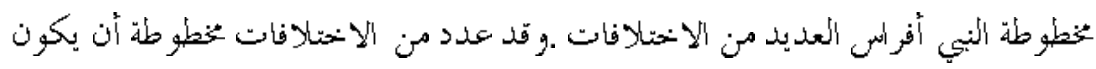

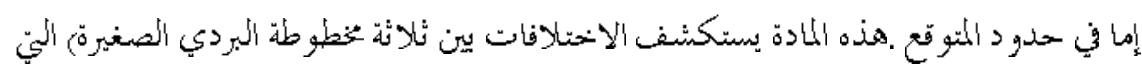

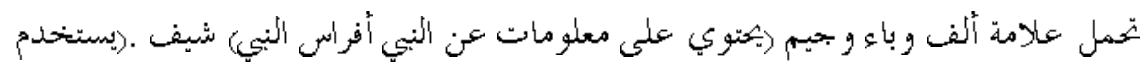

443 Studia Islamika, Vol. 17, No. 3, 2010 


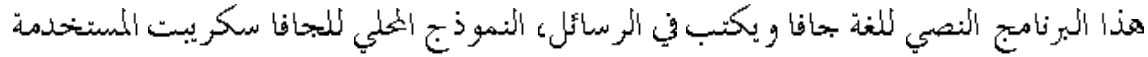

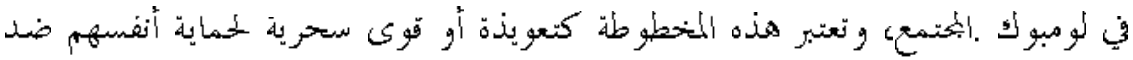

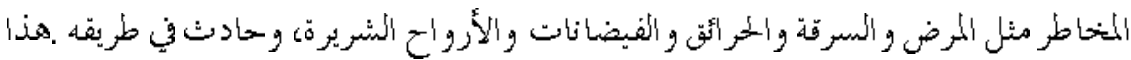

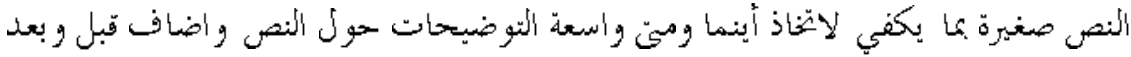

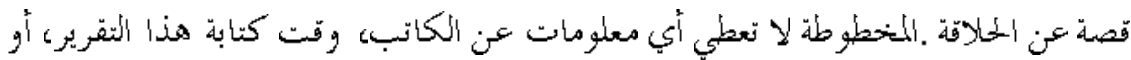

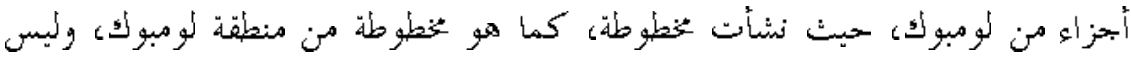
الئفاصيل كولو فو انس (colophons) المئا حمة.

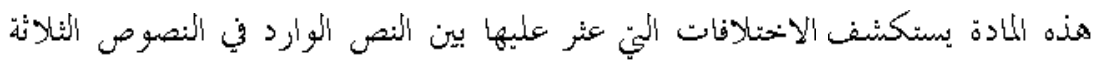

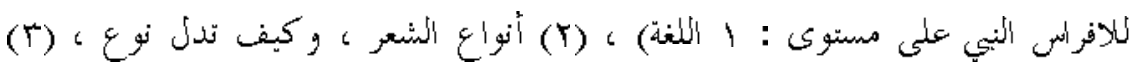

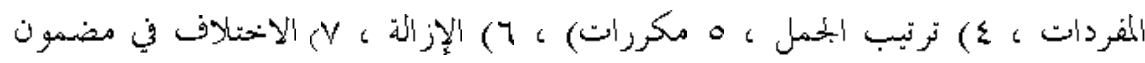

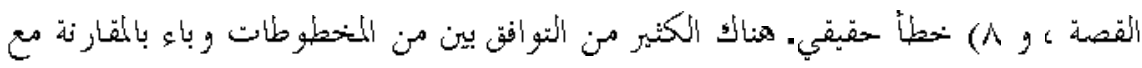

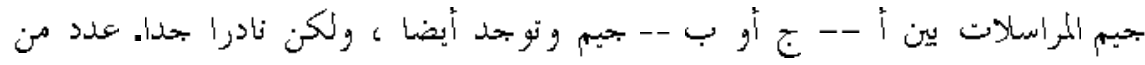

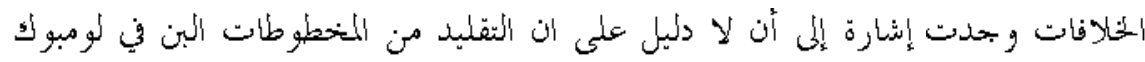

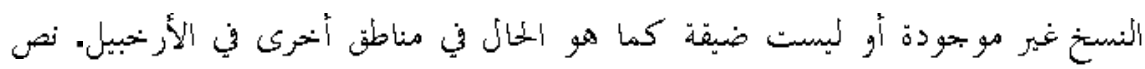

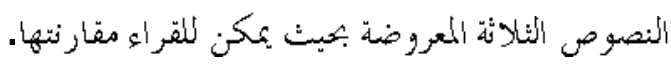

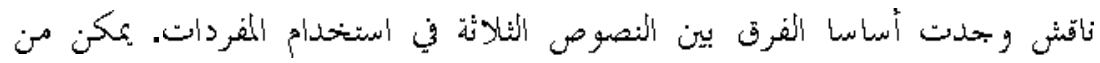

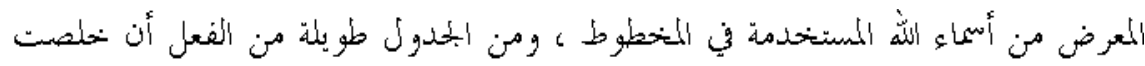

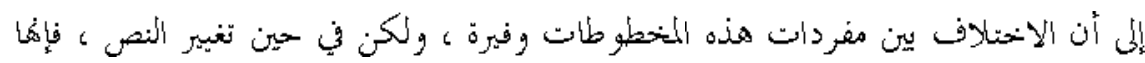

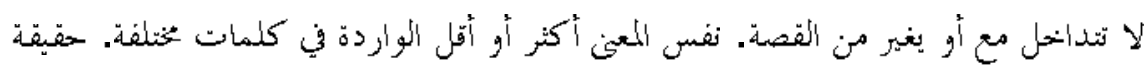

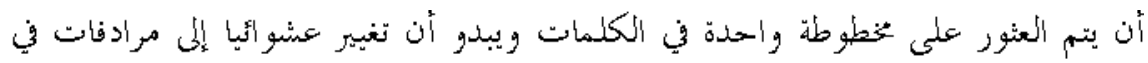

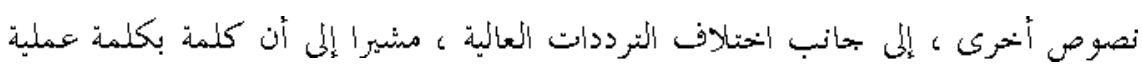

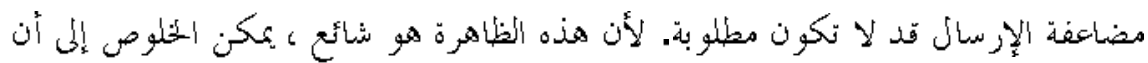

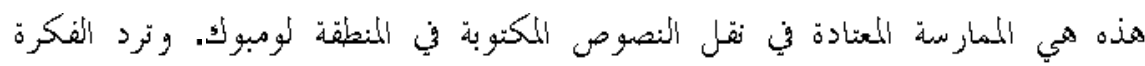

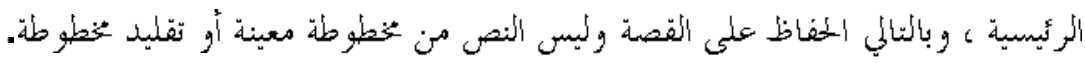

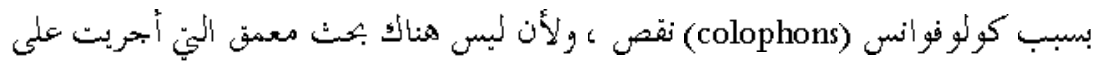

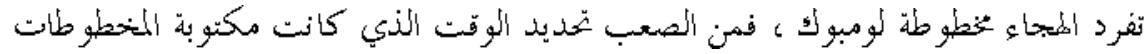




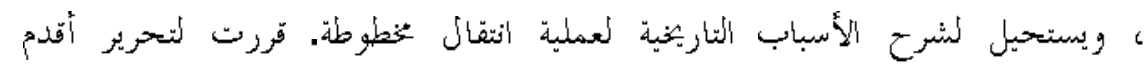

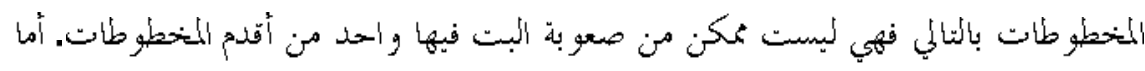

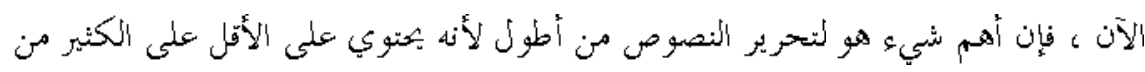

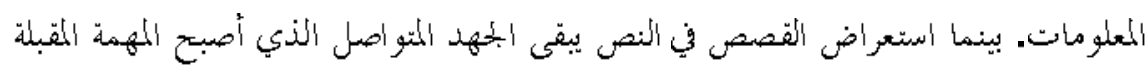

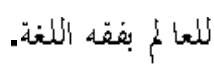




\section{Dick van der Meij}

\section{The Shaving of the Prophet's Hair (Nabi Aparas): The Philology of Lombok Texts}

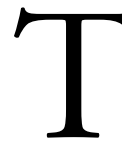
he Islamic textual history from the island of Lombok in Indonesia has so far been little explored. This is a pity as this history may provide important information about the way Islam has been perceived by the Sasak people, and the possible role the textual tradition has played in local and supralocal perspectives on the two varieties of Islam, waktu telu and waktu lima, ${ }^{1}$ on the island. Other aspects of the manuscript-based textual tradition of the Sasak have also only received scant attention. ${ }^{2}$ The reason for this is that many manuscripts with an Islamic content (or any other content for that matter) wait to be edited and translated. Manuscript production in Lombok has been enormous and thousands and thousands of manuscripts have been produced. It is therefore a paradox that despite this wealth of manuscripts, philologists have virtually ignored this text tradition and only a few text editions have seen the light so far. ${ }^{3}$ The overwhelming textual variety encountered in manuscripts from Lombok and their sheer numbers make the application of many traditional philological methods and approaches hazardous, and methodological uncertainty is an undesired situation in scholarship. One of the problems in philology seems to be the absence of consensus on yardsticks and when and how to apply them. I think the variation in the manuscripts of the Nabi Aparas is significant, but for others it may be that the variation among the manuscripts is well within expected limits. Apparently, a difference in expectations is at work here, but precisely these individual and subjective expectations are difficult to standardize. Whatever the case, for me the textual tradition of the Sasak people is fluent, and I strongly doubt whether a tradition of painstakingly copying 
texts word for word ever existed or that 'copying' texts indeed meant to change them to the copyist own desires, or that, apparently, the variation that was the result of these copying efforts was acceptable. We should perhaps rethink the meaning of the words 'copy' and 'copying' in this context as no true 'copies' are really about. In my view, there is no tradition of copying manuscripts but a tradition of the transmission of texts without or with only a limited component of real copying. The present article aims to discuss some of the variety found in manuscripts from Sasak provenance from Lombok to prove this point.

Below we are concerned with a comparison of three tiny palm leaf manuscripts (lontar) (dubbed A, B, and C) all three of which contain the Javanese text Nabi Aparas, or the Shaving of the Prophet. ${ }^{4}$ The manuscripts are written in the so-called jejawen script, which is the local form of Javanese script as used in Lombok. The manuscripts are regarded as jimat or magical charms and are considered efficacious for the protection against the many dangers one encounters in life such as sickness, burglary, fire, flooding, devils and evil spirits, and the hazards of travel. The manuscripts are so small that they can be carried any place at all times (as indeed recommended in the texts), and extensive explanations of the protective qualities of the text are added before and after the story of the shaving proper. ${ }^{5}$ The question may be asked here whether these manuscripts were indeed intended to carry a text actually to be read or rather sung, or whether the text is there to fulfill the requirements of a written jimat. The manuscripts give no information whatsoever about the author, copyist, the date of writing, or from what part of Lombok they originate; as usual for manuscripts from the Lombok area, no detailed colophons are provided. ${ }^{6}$

I chose this tiny text as an example of the Sasak textual tradition because it is my impression that we may be in danger of spending too much time (nowadays no longer available and for which funding is often no longer provided) in comparisons of long texts in order to comprehend a textual tradition. I propose that using a small text may do the job just as well and in much less time.

Below, I will present transliterations of the complete texts of the shaving of the Prophet and the texts that immediately precede and follow them from the three manuscripts mentioned above. ${ }^{7}$ The number of stanzas of the texts preceding the story of the hair shaving are indicated in regular font (a-), those of the text of the shaving in numerals (1-), and the stanzas of the text after that of the shaving in capitals (A-). The discussion on 
the variation between the texts in the manuscripts below, however, only refers to the texts of the story of the Nabi Aparas proper and not to the accompanying texts. The transliterations of these texts are provided for their content only. As a translation of the complete contents of manuscript A has been published before (Van der Meij 1996a), a translation of the shaving of the Prophet and surrounding texts from manuscript $\mathrm{C}$ has been added as appendix 2 .

Variation between the manuscripts is encountered on many levels, and the following will be discussed below 1 . language; 2 . the poetic meters and if and how verse forms are indicated; 3 . vocabulary; 4 . line sequence; 5. repetition; 6 . omission; 7. obvious differences in the story, as well as 8 . mistakes. ${ }^{8}$ There is a large number of correspondences between $\mathrm{A}$ and $\mathrm{B}$ as opposed to C. Correspondence between A - C or B - C occurs, but much more rarely.

\section{Language}

To appreciate the textual tradition of the Sasaks the following is important to bear in mind. The Sasaks of Lombok speak a variety of Sasak dialects. ${ }^{9}$ However, linguists are uncertain about the exact number of dialects and also the Sasak themselves have various and often conflicting ideas about their language, while political, sociological, and historical reasons lead many Sasak to consider the particular dialect they speak as the only Sasak language proper. ${ }^{10}$

Like other peoples in the Javanese cultural sphere such as the Sundanese in West Java and the Madurese on Madura and in East Java, the Sasak people also preferred to use Javanese as their literary language rather than Sasak, and manuscripts written in Sasak are comparatively rare; manuscripts written in Javanese far outnumber those written in Sasak. The fact that Javanese is a foreign language for the Sasak may account for the kind of Javanese used in the manuscripts, and may also explain differences that occur between manuscripts.

The Javanese language used in texts from Lombok is quite consistent and does not differ much from place to place or even from text to text. It does seem however that the Javanese vocabulary used in texts is not very extensive and the grammatical, especially the morphological rules of Javanese are not used optimally or consistently and therefore are not always the way Javanese 'proper' would have it. 
Since virtually all texts are in a poetic form, the language used in the texts is heavily influenced by the requirements of poetry and poetic meters, often detrimental to Javanese grammatical rules. The rules governing the use of what are popularly called high and low Javanese (from high to low: krama inggil, krama, and ngoko and all levels in between) are usually ignored or at least not used consistently, and the question may be asked whether the Sasak people were aware of these levels or simply considered the words from the various levels as mere synonyms. The validity of these remarks has to be demonstrated by more investigation into the issue, but the evidence as revealed in the large number of manuscripts from Sasak provenance I have seen leads me to think that the sociolinguistic differences between the various vocabularies of politesse are not keenly felt, if at all. ${ }^{11}$ This having been said, we should be careful not to judge Sasak Javanese with the Javanese as used in Central Java in mind, and we should be mindful to appreciate Sasak Javanese on its own merits.

Sometimes Sasak or Balinese words are used in Javanese texts and occasional Sasak or Balinese affixes are used as well (in our sample here, stanza B 11-7 and C 23-4 use the suffix -in). ${ }^{12}$ Some manuscripts from Sasak provenance also use (often a limited number of) Malay/Indonesian vocabulary such as in the case of MS C of the Nabi Aparas discussed here, in stanzas a: artinya kutahwi tyada, hanya, 13, jadi, suda, 15, tidah ada samanya, tidah lama, 16, inilah dawun, suda, dibuwat, kapada, amamakeh (from pakai) 17, disuruh 23, penyakit, etc. The use of this Malay/ Indonesian vocabulary in the manuscripts is entirely unpredictable. The reasons behind the sudden use of this vocabulary are as yet unknown.

\section{Poetic meters, Tembang macapat}

Virtually all texts from Lombok are written in a Javanese verse form named tembang macapat. ${ }^{13}$ There are many different macapat meters that are used in Java, Madura, and Bali, but the Sasak in Lombok usually limited themselves to the use of only six: sinom, dangdanggula, pangkur, durma, asmaradana, and maskumambang. ${ }^{14}$ Each macapat meter theoretically has a fixed number of lines per stanza, a fixed number of syllables per verse line, and a fixed vowel in the last syllable of each line. Nevertheless, the evidence from the manuscripts from the Sasak area suggests that, for them, these rules are either not strictly binding or not abided by, as much variation is found in all three aspects. The distribution of the text over contiguous meters varies as well; often we see that part of the text that is related in a one 
meter in one manuscript is told in another meter in another manuscript and this is also what happened to the story at hand.

MS A and B start with the meter sinom $(8 \mathrm{a}, 8 \mathrm{i}, 8 \mathrm{a}, 8 \mathrm{i}, 7 \mathrm{i}, 8 \mathrm{u}, 7 \mathrm{a}$, $8 \mathrm{i}, 12 \mathrm{a}) .{ }^{15}$ Ms $\mathrm{A}$ gives no hint as to what meter is used. $\mathrm{B}$ indicates that the meter is sinom by mentioning its name in full, and comparison with A indicates that A starts with sinom as well. C starts with pangkur (8a, $11 \mathrm{i}, 8 \mathrm{u}, 7 \mathrm{a}, 12 \mathrm{u}, 8 \mathrm{a}, 8 \mathrm{i}$ ) and mentions the abbreviation 'pang', which is indicative of that meter. A has seven stanzas preceding the start of the story, B has eight while $\mathrm{C}$ only has four of which the last only has three lines. The story of the shaving of the Prophet is told in 20, 19, and 23 stanzas respectively. A and B tell the story in Sinom throughout while $\mathrm{C}$ changes from pangkur to sinom after stanza 13 indicating the change by mentioning the abbreviation ' $s i$ ' which is indicative of sinom. Because pangkur has seven lines per stanza as opposed to sinom with nine, the story material is told in more stanzas in $\mathrm{C}$ than in $\mathrm{A}$ and $\mathrm{B}$, as a stanza in pangkur is simply shorter than one in sinom. This means that the story content had to be adapted to the meter, which has consequences for the vocabulary and verb affixation because of the 'obligatory' number of syllables per verse line and the obligatory end vowel of each line. All three manuscripts add seventeen stanzas to the story in asmaradana ( $8 \mathrm{i}, 8 \mathrm{a}, 8 \mathrm{e} / \mathrm{o}, 8 \mathrm{a}, 7 \mathrm{a}, 8 \mathrm{u}, 8 \mathrm{a}$ ), indicated in A by asmaradana, in B by smar and in $\mathrm{C}$ by smaran.

The numbers of syllables per verse line and the final vowel as indicated above probably form the 'ideal' structures of these meters, but the manuscripts often show a different use of numbers. Table 1 below shows the poetic structures of the meters that relate the story of the Nabi Aparas. It is clear from browsing the table that hardly any line corresponds completely with the 'theoretical' structure of the meter. The number of syllables per verse line is generally lower than the number required by their 'theoretical' numbers. ${ }^{16}$ Sinom also shows some instances where the vowel in the final syllable is /o/, which is also usually not found (MS A 5 and 8 and MS B 6 and 8). A 19.3 unexpectedly ends in /i/ as does B 17.9 whereas /a/ was expected. C 6.3 ends in /a/ instead of /u/. 
Table 1: The meters

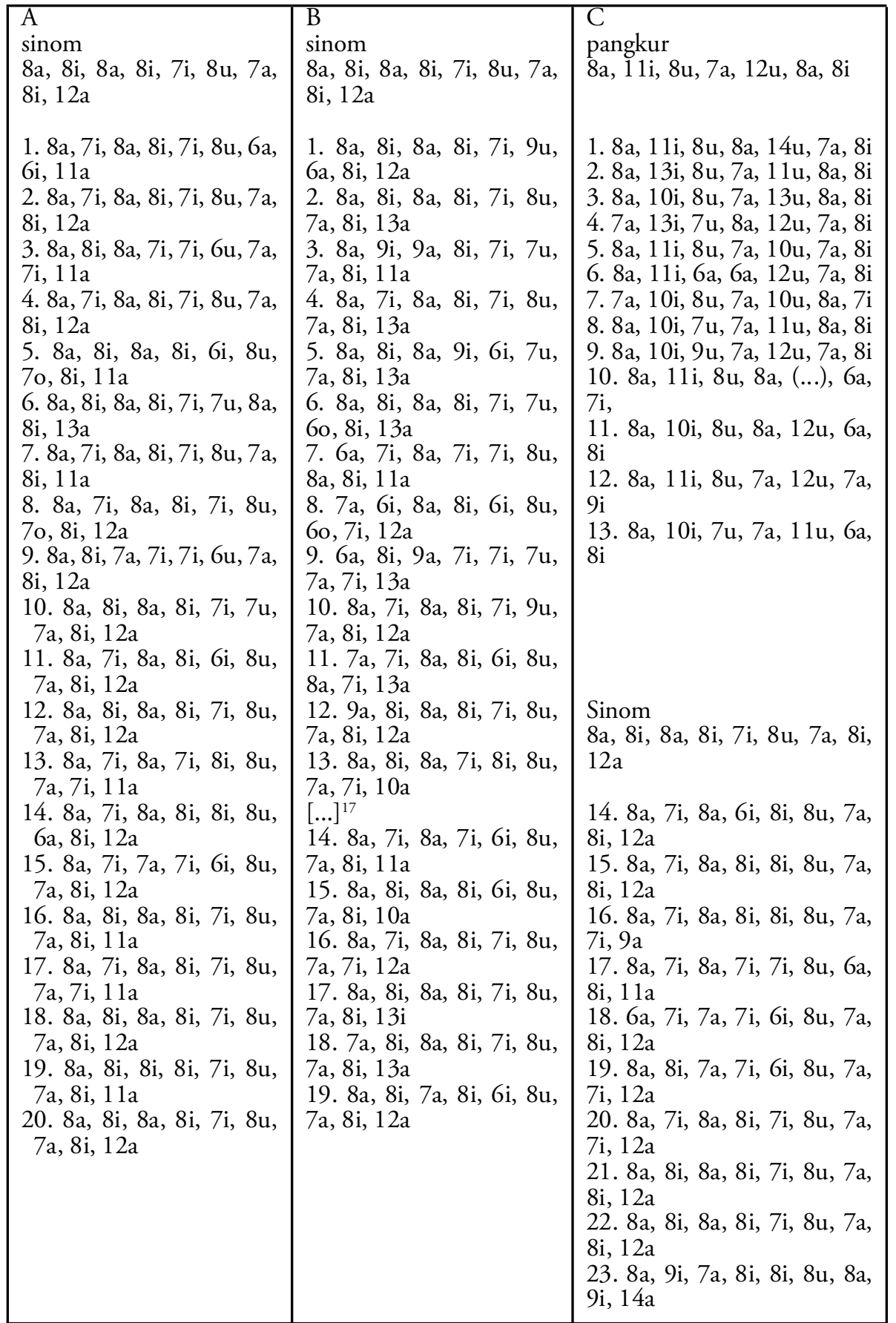


Another issue in connection with the requirements of the verse form is the break of a sentence over different verse lines. Usually the verse lines stay within the constraints of syntactic units. In the sample we use there is one striking instance where the divide falls between a noun (nugraha) and its possessive suffix (-nira). Ms A 4/7-8 has katur/ayunan tuwan, nugrahanira/ yang widi, where the noun and its suffix stay together, while B 4/7-8 has srata bakta nugraha, nira sira sang yang widi and C 5/4-5 has srata mbakta nu/5b/ grahan, nira pangeran yang mahaluhur where the noun nugraha and its suffix nira have been split over two verse lines.

\section{Vocabulary}

Between the manuscripts, we often see that synonyms are used in the same position in the three manuscripts of the text. Where we find nabi (Prophet) in one position in one manuscript we may easily find rasul (messenger) in another in the same position and the same is true for the words paras, kuris, and cukur ('to shave') which between manuscripts have been used interchangeably as well. The texts have many other examples such as the interchangeability of yang agung, yang widi, yang mahatinggi, yang mahatinggil, yang mahamulya, hyang lubur, hyang mahaluhur, and yang manon - next to ala - all indicative of Allah (see the table 3 below). These choices of synonyms do not result in a change in the overall meaning of the story. Whether Jibrail requests something from yang manon on behalf of the rasul or whether, in another manuscript in the same position he asks something of yang mahatinggi for the nabi boils down to the same thing, but the actual wordings are, of course, different. ${ }^{18}$

Changes in vocabulary also occur in other places where ngoko, krama, krama inggil and poetic vocabulary are used interchangeably within the texts of the three manuscripts, that is to say, if we can talk about true synonyms because sociolinguistically speaking they are not. Let us consider one of the key words in the text: paras. Paras is the krama inggilvariety of cukur, which is both ngoko and krama. If we compare the manuscript as to the use of paras, cukur and kuris the following picture emerges: ${ }^{19}$

\begin{tabular}{|l|l|l|l|}
\hline & A & B & C \\
\hline paras & 17 & 16 & 14 \\
\hline cukur & 2 & 1 & 6 \\
\hline kuris & 4 & 4 & 2 \\
\hline
\end{tabular}


Table 2: The distribution of paras, cukur, and kuris in their various verb forms over de texts is as follows. Bold indicates correspondences between the manuscripts. ${ }^{20}$

\begin{tabular}{|c|c|c|c|c|c|}
\hline A & & B & & $\mathrm{C}$ & \\
\hline 1.3 & Pinaras & 1.3 & aparas & 1.3 & acukur \\
\hline 1.9 & Aparas & 1.9 & aparas & 2.1 & aparas \\
\hline 2.1 & Amaras & 2.1 & amaras & 2.3 & ańukur \\
\hline 2.3 & Aparas & 2.3 & aparas & 2.5 & acukur \\
\hline 2.9 & Aparas & 2.9 & aparas & -- & -- \\
\hline 3.3 & Pinaras & 3.3 & aparas & 3.6 & aparas \\
\hline 3.9 & Aparas & 3.9 & aparas & 4.5 & aparas \\
\hline 5.5 & Akuris & 5.5 & akuris & 6.4 & aparas \\
\hline 5.9 & Pinaras & 5.9 & pinaras & 7.1 & aparas \\
\hline 6.9 & Pinaras & 6.9 & pinaras & 8.4 & aparas \\
\hline-- & -- & -- & -- & 8.5 & amaras \\
\hline 7.3 & Aparas & 7.3 & aparas & 8.7 & akuris \\
\hline-- & -- & -- & -- & 9.1 & amaras \\
\hline 7.9 & Aparas & 7.9 & aparas & 9.6 & acukur \\
\hline 8.3 & Pinaras & 8.3 & pinaras & 10.2 & aparas \\
\hline-- & -- & 9.3 & aparas & 11.5 & aparas \\
\hline 9.9 & Aparas & 9.9 & aparas & 12.5 & aparas \\
\hline 10.8 & Akuris & 10.8 & akuris & -- & -- \\
\hline 10.9 & Aparas & 10.9 & aparas & 13.5 & aparas \\
\hline 13.5 & Akuris & 13.5 & akuris & 16.5 & akuris \\
\hline 14.3 & Amaras & -- & -- & 17.3 & manguris \\
\hline 14.6 & Añukur & -- & -- & 17.6 & ańukur \\
\hline 14.9 & Pinaras & -- & -- & 14.9 & pinaras \\
\hline 15.1 & Pinaras & 14.1 & pinaras & 18.1 & aparas \\
\hline 15.8 & Akuris & 15.8 & akuris & 15.8 & akuris \\
\hline 20.6 & Acukur & 19.6 & acukur & 23.6 & acukur \\
\hline
\end{tabular}

It is interesting to note that $A$ and $B$ up to stanza 14 have quite a few verbs with the infix -in- and $C$ none at all. After stanza 13 they are still more found in $\mathrm{A}$ and $\mathrm{B}$ and only once in $\mathrm{C}$.

Another example of the wide lexical variation found among the three manuscripts is the various names that are used for Allah and their position in the texts. They are as follows 
Hyang Widi

Hyang Luhur

Hyang Agung

Pangeran Yang Mahalubur

Hyang Suksma

Yang Ma'atinggi

Yang Manon

Yang Mahatinggil

Alab/Ala

Yang Mahamulya
The One Who Leads ${ }^{21}$

The High One

The Great One ${ }^{22}$

God The Most High

The Immaterial One ${ }^{23}$

The Highest

The All Seeing

The Highest

Allah

The Most Sublime

Table 3: The various expressions used to indicate Allah, total correspondences are indicated in bold. ${ }^{24}$

\begin{tabular}{|l|l|l|l|l|l|}
\hline A & & B & & C & \\
\hline 3.5 & Hyang Widi & & -- & & -- \\
\hline 4.5 & Hyang Widi & $\mathbf{4 . 5}$ & Hyang Widi & 5.1 & Hyang Suksma \\
\hline 4.6 & Hyang Luhur & 4.5 & Yang Agung & 5.3 & Hyang Agung \\
\hline 4.8 & Yang Widi & $\mathbf{4 . 8}$ & Yang Widi & 5.6 & $\begin{array}{l}\text { Pangeran Yang } \\
\text { Mahaluhur }\end{array}$ \\
\hline 5.1 & Hyang & & -- & & -- \\
\hline 5.2 & Hyang Widi & 5.2 & Yang Widi & 6.1 & Yang Suksma \\
\hline 6.2 & Widi & 6.2 & Sang Widi & 7.3 & Yang Agung \\
\hline 6.4 & $\begin{array}{l}\text { Yang } \\
\text { Ma'atinggi }\end{array}$ & $\mathbf{6 . 4}$ & $\begin{array}{l}\text { Yang } \\
\text { Ma'atinggi }\end{array}$ & 7.5 & Yang Mahaluhur \\
\hline 6.7 & Yang Manon & $\mathbf{6 . 7}$ & Yang Manon & 8.1 & Yang Suksma \\
\hline 6.8 & $\begin{array}{l}\text { Yang } \\
\text { Ma'atinggi }\end{array}$ & $\mathbf{6 . 8}$ & $\begin{array}{l}\text { Yang } \\
\text { Ma'atinggi }\end{array}$ & 8.2 & Yang Mahatinggil \\
\hline 7.1 & $\begin{array}{l}\text { Sang Yang } \\
\text { Suksma }\end{array}$ & 7.1 & Yang Suksma & 8.6 & Yang Suksma \\
\hline 8.7 & $\begin{array}{l}\text { Sang Yang } \\
\text { Manon }\end{array}$ & 8.7 & Yang Manon & & -- \\
\hline 9.5 & Hyang Widi & 9.5 & Yang Widi & & -- \\
\hline & -- & & -- & 12.2 & Yang Widi \\
\hline 10.2 & Sang Yang Widi & 10.2 & Yang Widi & 12.7 & Yang Mahatinggi \\
\hline 10.3 & Hyang & 10.3 & Yang & 13.1 & Yang \\
\hline 10.6 & Pangeran & 10.6 & $\begin{array}{l}\text { Pangeran Kang } \\
\text { Agung }\end{array}$ & 13.3 & Kang Agung \\
\hline & -- & & -- & 13.4 & Twan \\
\hline
\end{tabular}




\begin{tabular}{|l|l|l|l|l|l|}
\hline 11.1 & Yang Suksma & $\mathbf{1 1 . 1}$ & Yang Suksma & 14.1 & Yang Suksma \\
\hline 12.1 & Yang & 12.1 & Alah & 15.1 & Yang \\
\hline 13.7 & Yang Suksma & $\mathbf{1 3 . 7}$ & Yang Suksma & 16.7 & Yang Suksma \\
\hline 14.5 & Widi & & -- & & -- \\
\hline 14.8 & $\begin{array}{l}\text { Yang Kang } \\
\text { Ma'atinggi }\end{array}$ & & -- & 17.8 & Yang Mahatinggi \\
\hline 18.7 & Alah & $\mathbf{1 7 . 7}$ & Alah & $\mathbf{2 1 . 7}$ & Alah \\
\hline 18.9 & Yang Suksma & $\mathbf{1 7 . 9}$ & Yang Suksma & 21.9 & $\begin{array}{l}\text { Pangeran Yang } \\
\text { Mahamulya }\end{array}$ \\
\hline 19.1 & Ala & $\mathbf{1 8 . 1}$ & Ala & 22.1 & Yang Mahamulya \\
\hline
\end{tabular}

Finally we will have a look at the verbs used in the manuscripts. The tables below show all the verbs used in the three texts apart from paras and its variations, which have already been mentioned in, table 2 . We will have a look at the verb that has been used, not at its actual affixed form. When agreement occurs, they have been indicated in bold. The differences up to stanza A-B 11 and C 14 are often due to the requirements of the meter, because the final vowels in pangkurverse lines are not the same as those in sinom in the same position in the story (see the table below). Since $\mathrm{C}$ joins $\mathrm{A}$ and B after stanza 13 in its use of sinom, verb agreement becomes much more frequent.

Table 4: Metri causa verb differentiation. ${ }^{25}$

\begin{tabular}{|l|l|l|l|l|l|}
\hline A & & B & & C & \\
\hline 1.3 & Pinaras & 1.3 & aparas & 1.3 & acukur \\
\hline 1.4 & wĕntěn prapti & $\mathbf{1 . 4}$ & wĕntěn prapti & 1.4 & ana prapta \\
\hline 2.1 & Amaras & $\mathbf{2 . 1}$ & amaras & 2.3 & anukur \\
\hline 2.3 & Aparas & $\mathbf{2 . 3}$ & Aparas & 2.5 & acukur \\
\hline 3.2 & Angling & $\mathbf{3 . 2}$ & angling & 3.5 & $\begin{array}{l}\text { den-lingira } \\
\text { amuwus }\end{array}$ \\
\hline 5.5 & kinen akuris & $\mathbf{5 . 5}$ & kinen akuris & 6.4 & kinen aparas \\
\hline 6.1 & Anabda & $\mathbf{6 . 1}$ & anabda & 7.3 & matur \\
\hline 6.6 & Arawuh & $\mathbf{6 . 6}$ & rawuh & 7.7 & prapti \\
\hline 7.3 & Aparas & $\mathbf{7 . 3}$ & aparas & 8.7 & akuris \\
\hline 8.6 & Matur & $\mathbf{8 . 6}$ & matur & 10.4 & matura \\
\hline 9.1 & Mojar & $\mathbf{9 . 1}$ & mojar & 11.3 & matur \\
\hline 9.6 & Wruh & $\mathbf{9 . 6}$ & wruh & 12.1 & wikan \\
\hline 9.7 & ngandika & $\mathbf{9 . 7}$ & ngandika & 12.2 & andikaning \\
\hline 10.7 & Kinarya & $\mathbf{1 0 . 7}$ & kinarya & 13.5 & jadi \\
\hline
\end{tabular}


Only two occurrences show the same verb (maturlandika) but with a different suffix $(-a$ and $-i n g)$ so that the requirement of the meter is fulfilled. The difference in verb is in some cases only a matter of a change in vowel and occurs only once (prapta/prapti). Both forms are poetic.

Table 5: The rest of the verbs used in the manuscripts apart from those mentioned in other tables, total correspondences are indicated in bold. ${ }^{26}$

\begin{tabular}{|l|l|l|l|l|l|}
\hline A & & B & & C & \\
\hline & -- & & -- & 1.1 & Kawarnaa \\
\hline 1.5 & atataken & 1.5 & matur pataken & 1.5 & atur pataken \\
\hline 1.9 & Taken & $\mathbf{1 . 9}$ & taken & -- & -- \\
\hline & -- & 2.5 & rawuh & $\mathbf{2 . 7}$ & Rawuh \\
\hline 3.1 & wartanana & $\mathbf{3 . 1}$ & wartanana & & -- \\
\hline $\mathbf{3 . 6}$ & Aprang & $\mathbf{3 . 6}$ & aprang & $\mathbf{4 . 1}$ & Aprang \\
\hline $\mathbf{4 . 1}$ & Maca & $\mathbf{4 . 1}$ & maca & $\mathbf{4 . 5}$ & Maca \\
\hline 4.2 & Dateng & $\mathbf{4 . 2}$ & dateng & 4.6 & Prapta \\
\hline $\mathbf{4 . 3}$ & ambakta & $\mathbf{4 . 3}$ & ambakta & $\mathbf{4 . 7}$ & Ambakta \\
\hline 4.4 & Matur & & -- & & -- \\
\hline & -- & 4.5 & dateng & 5.2 & Tumarek \\
\hline 4.6 & Sabda & 4.6 & ingutus & $\mathbf{5 . 3}$ & Ingutus \\
\hline 4.7 & Katur & 4.7 & bakta & 5.4 & Mbakta \\
\hline 4.9 & Katur & 4.9 & umatur & 5.6 & Matur \\
\hline $\mathbf{5 . 2}$ & Sabda & $\mathbf{5 . 2}$ & sabda & $\mathbf{6 . 1}$ & Sabda \\
\hline $\mathbf{5 . 3}$ & Wěntěn & $\mathbf{5 . 3}$ & wĕntěn & $\mathbf{6 . 2}$ & Wěntĕn \\
\hline 5.4 & Pasti & 5.4 & pinasti & & -- \\
\hline $\mathbf{5 . 6}$ & amuwus & $\mathbf{5 . 6}$ & amuwus & $\mathbf{6 . 5}$ & Amuwus \\
\hline $\mathbf{6 . 3}$ & mangkat & $\mathbf{6 . 3}$ & mangkat & 7.4 & Mangkat \\
\hline 6.4 & Matur & 6.4 & matur & 7.5 & Umatura \\
\hline 6.8 & Matur & 6.8 & matur & 8.2 & Umatur \\
\hline & -- & & -- & & Amaras \\
\hline & -- & & -- & 9.1 & Amaras \\
\hline 7.4 & awangsul & 7.4 & wangsul & 9.2 & Lumaris \\
\hline 7.5 & Dateng & $\mathbf{7 . 5}$ & dateng & & -- \\
\hline $\mathbf{7 . 6}$ & Umatur & $\mathbf{7 . 6}$ & umatur & $\mathbf{9 . 3}$ & Umatur \\
\hline 7.8 & kinen & $\mathbf{7 . 8}$ & kinen & 9.5 & andika \\
\hline 8.1 & Anabda & $\mathbf{8 . 1}$ & anabda & 9.7 & Lingnya \\
\hline $\mathbf{8 . 8}$ & Prapti & $\mathbf{8 . 8}$ & prapti & $\mathbf{1 0 . 7}$ & Prapti \\
\hline $\mathbf{8 . 9}$ & Prapta & $\mathbf{8 . 9}$ & prapta & $\mathbf{1 1 . 1}$ & Prapta \\
\hline & & & & & \\
\hline
\end{tabular}




\begin{tabular}{|c|c|c|c|c|c|}
\hline 9.5 & Wruh & 9.5 & wruh & 11.7 & Weruh \\
\hline 10.1 & mangkat & 10.1 & mangkat & 12.6 & Mangkat \\
\hline 10.2 & Umatur & 10.4 & umatur & 12.7 & Matur \\
\hline 10.4 & Umatur & 10.4 & umatur & 13.2 & Umatur \\
\hline & -- & & - & 13.4 & Matur \\
\hline 11.1 & pangandikaning & 11.1 & angandika & 14.1 & $\begin{array}{l}\text { wenten } \\
\text { pramaning }\end{array}$ \\
\hline 11.3 & mangkata & 11.3 & mangkata & 14.3 & Mangkata \\
\hline 11.4 & mañjing & 11.4 & mañjing & 14.5 & Mañjing \\
\hline 11.5 & Ambilna & 11.5 & ambilen & 14.4 & Angambil \\
\hline 11.7 & sun-arani & 11.7 & ingsun-arani & & -- \\
\hline 11.8 & Ambilna & 11.8 & ambil & 14.7 & Ambila \\
\hline 11.9 & Kinarya & 11.9 & kinaryanĕn & 14.9 & Karyaněn \\
\hline 12.2 & umangkat & 12.2 & umangkat & 15.2 & Mangkat \\
\hline 12.3 & angambil & 12.3 & angambil & 15.3 & Angambil \\
\hline 12.4 & ańjumput & 12.4 & anjumput & 15.4 & Ingambil \\
\hline 12.8 & Binakta & 12.8 & binakta & 15.8 & Binakta \\
\hline 12.9 & Prapta & 12.9 & prapta & 15.9 & Dateng \\
\hline 13.1 & Ngaturi & 13.1 & ngaturing & 16.1 & Asung \\
\hline 13.4 & anggenĕn & 13.4 & anggenĕn & 16.4 & Amamakeh \\
\hline 13.6 & karyanĕn & 13.6 & karyanĕn & 16.6 & Dibuwat \\
\hline 13.7 & Kinen & 13.7 & kinen & 16.7 & saking pangkon \\
\hline 14.1 & Lingira & & -- & 17.1 & Sabdana \\
\hline 14.4 & Umatur & & -- & 17.4 & Lingnya \\
\hline 14.6 & kinen & & -- & 17.6 & disuruh \\
\hline 15.6 & ngabakti & 14.6 & ngěbakti & 18.6 & Sembahyang \\
\hline 15.7 & tumingal & 14.7 & tumingal & & -- \\
\hline 16.1 & tinampanan & 15.1 & tinampanan & 19.1 & Tinampanan \\
\hline 16.2 & Tibeng & 15.2 & tibeng & 19.2 & Tibeng \\
\hline 16.3 & angandika & 15.3 & angandika & 19.3 & Andika \\
\hline 16.7 & ana tibeng & 15.7 & ana tibeng & 19.7 & ana tibeng \\
\hline 16.8 & amuwus & 15.8 & amuwus & 19.8 & Lingnya \\
\hline 17.1 & Tibeng & 16.1 & tibeng & 20.1 & Tibeng \\
\hline 17.3 & tinampanan & 16.3 & tinampanan & 20.3 & Tinampanan \\
\hline 17.5 & amuwus & 16.5 & amuwus & 20.5 & Ngandika \\
\hline 17.7 & angandika & 16.7 & angandika & 20.7 & Umatura \\
\hline 18.4 & Kagĕm & 17.4 & kagĕm & 21.4 & Kagĕm \\
\hline 18.5 & ana tibeng & 17.5 & ana tibeng & 21.5 & ana tibeng \\
\hline 18.6 & Rinĕbut & 17.6 & rinĕbut & 21.6 & Rinĕbut \\
\hline 18.8 & Datĕng & 17.7 & datěng & 21.7 & Ingandika \\
\hline 18.9 & angandika & 17.9 & angandika & & -- \\
\hline
\end{tabular}




\begin{tabular}{|l|l|l|l|l|l|}
\hline $\mathbf{1 9 . 3}$ & mangkata & $\mathbf{1 8 . 3}$ & mangkata & $\mathbf{2 2 . 3}$ & Mangkata \\
\hline $\mathbf{1 9 . 6}$ & amupuwa & $\mathbf{1 8 . 6}$ & amupuwa & $\mathbf{2 2 . 6}$ & Amupuwa \\
\hline $\mathbf{1 9 . 7}$ & krĕyanĕn & $\mathbf{1 8 . 7}$ & karyanĕn & $\mathbf{2 2 . 7}$ & Karyanĕn \\
\hline $\mathbf{1 9 . 9}$ & Talekna & $\mathbf{1 8 . 9}$ & talekna & $\mathbf{2 2 . 9}$ & Talekna \\
\hline $\mathbf{2 0 . 2}$ & sun-luputaken & $\mathbf{1 9 . 2}$ & sun-luputaken & $\mathbf{2 3 . 2}$ & sun-luputaken \\
\hline 20.4 & anempĕni & 19.4 & animpěni & 23.4 & Nimpĕnin \\
\hline 20.8 & Prapta & $\mathbf{1 9 . 8}$ & prapta & 23.8 & sun-luputaken \\
\hline & -- & & -- & 23.9 & Animpĕna \\
\hline
\end{tabular}

The overall picture of the verb correspondence between the manuscripts is as follows. From the 114 verbs considered, the total correspondence is $50,8 \%$ (58 out of 114 ), A-B correspondence is $84,2 \%$ (96 out of 114), between A-C $50 \%$ (57 out of 114), and between B-C 53,5\% (61 out of 114).

\section{Line sequence}

Difference in line sequence occurs in A and B 11, which mention that Gabriel went into Heaven and quickly, fetched the kastuba leaf (mañjing/16a/a sira ing swargi, ambilna den-aglis), whereas C 14 mentions that Gabriel has to fetch the leaf and then he is ordered to enter Heaven (angambil sireki, mañjinga maring swar/gadi).

\section{Repetition}

In the three manuscripts there is one example of a repetition the scribe made during the production process of the manuscript. It is found in manuscript A in stanza 15 lines 8 and 9. tatkala nabi akuris, / kapĕnĕtan sadaya samya tumingall, tatkala nabi akuris, / kapěnětan sadaya samya tumingal.

\section{Omission}

The most obvious omission occurs in manuscript $A$ at the very outset. It omits the basmallah, which often precedes any text from the Sasak area and is included in manuscripts B and C. A 2-5 asks of the day when the Prophet was shaven (miwah dinten punapi), while this question is omitted in B and C which have miwah rawuh punapi (why have your arrived) and ing mangke rawuh punapi (now has arrived), neither of which make much sense. 
A 20-9 and B 19-9 have sinalinan pinupuh brangta lénggawa (the verse form changes into asmaradana whereas $\mathrm{C}$ omits this, while C 23-9 also omits it but has sun-luputaken ing penyakit. maring sira kang arep animpena punika

\section{Mistakes}

Mistakes occur on the level of the vocabulary. C 4-5 tells us that the Prophet was reading the Krohu which is a mistake for the Koran. B 16-9 has nambar which does not exist while both other manuscripts (A 17-9 and C 20-9) have nambang $=1000$. The mistake may be explained as in Javanese script the sign for the $/ \mathrm{r} / \mathrm{and} / \mathrm{ng} /$ in the last position of a syllable may look alike. A 18-2 and B 17-2 use puñjul (superb) whereas C 21-2 has putus which does not make sense in this context. A 19-7 and B 18-7 have jimat (magical charm) whereas C 22-7 has simat, which does not exist. A possible explanation for these mistakes may be that the copyist had insufficient knowledge of what he was scribing and possibly by misreading a letter copied something that was faulty, unnoticed by him because of his insufficient knowledge of Javanese.

It also occurs in more dramatic ways, such as A 5-9 which has [...] ing masa paduka almba pinaras (when you will be shaved), B 5-9 has imam sapa duk tatkala amba pinaras (who will lead when I will be shaven), while C 7-1 has padu mangke aparas (no translation possible), all three of which fit in awkwardly and do not make much sense.

One glaring mistake is that manuscript B the scribe has omitted a complete stanza in his/her copying effort. C 10 has is missing one line, as it contains only six lines rather than seven.

\section{Obvious differences in the story}

Some instances of differences are that A and B 3-9 tell that the Prophet was waging war against his enemy, the King of Lahat, while C 4-2 omits this and tells that he is fighting in the cause of Allah (aprang sabilulab). In B is also told that he was fighting a sabil war, which is not mentioned at all in A. A 2-9 wonders about the Prophet's age when he was shaved (lawan pinten umure tatkalaparas) while B 2-9 and C 3-3 wonder about the number of the Prophet's hairs. 
Stanzas A 17-18 and B 16-17 both mention that the Prophet has 133,332 strands of hair but manuscript C 20-21 mentions 133,333 hairs that is to say, just one more.

C 18. Mentions that the prayer consisted of two raka'at (rong rekahat al salam) which is lacking in A and B.

\section{Conclusion}

The freedom displayed in the distribution of the story material over stanzas in cantos of a specific meter, the reworking of story material from one meter into another, and the variation in the number of stanzas per canto telling the same part of a story is ubiquitous in manuscripts from Lombok provenance. However, the differences between the three manuscripts discussed above are mainly found in the use of vocabulary. From the exposition of the names of Allah used in the manuscripts, and from the lengthy tables of the verbs we may conclude that the lexical variation between the manuscripts is abundant, but while changing the texts, they do not disturb or change the story. More or less the same meaning is simply cast in different wordings. The fact that words found in the story in one manuscript are changed seemingly randomly for synonyms in other manuscripts, coupled with the high frequency of this occurrence, indicates that a word for word copying process of transmission may not be presupposed. Because of the common occurrence of this phenomenon, we cannot but conclude that this was standard practice in the written transmission of texts in the Sasak area. The idea seems to have been to transmit, and by so doing, preserve a story and not the text of a particular manuscript or manuscript tradition.

The above said has important consequences for editing a text because manuscripts do not seem to have been the focus of attention of the scribes/ copyists. Because of the occurrence of differences which have been made (more or less) purposefully and which are not the result of scribal errors, the traditional method of making a stemma and lists of variants seems to be almost impossible, since it is impossible to decide what a mistake is to begin with. This method is based on the assumption that mistakes and variations occur involuntarily and are involuntarily taken over by subsequent copyists, and that they are the result of human error. In this case human error remains, but is coupled with more or less purposeful changes the occurrences of which are even more unpredictable than mistakes. Thus, it is important in this tradition to look for meaningful 
divergences in the storyline, or at omissions in the transmission of the story in order to make a stemma and decide on the history of the textual transmission of the material. In our sample, this means, for instance, that the information that the Prophet was waging war against the King of Lahat would be sufficient proof that at least that part of the text as found in $\mathrm{A}$ and $\mathrm{B}$ was taken over from the same manuscript or from the same oral source of the story, but not $\mathrm{C}$ which lacks this information. At any case, it would prove an undeniable link between both manuscripts, setting them both apart from C. The use of synonyms may be far less useful for comparisons and stemma construction as this - perhaps not too random process, because of the limited number of available synonyms and thus the high likelihood that a certain synonym might be chosen - may not be as unpredictable as it seems.

My earlier research on the Puspakrama from Lombok revealed that grouping manuscripts based on their metrical structure is almost impossible. The table of the distribution of the cantos of 25 manuscripts I provided in 2002 seems to reveal clear patterns, but they elude the reader when we try to find exact or almost exact similarity. Apparently, apart from the freedom the copyists take by using their own judgments and inspiration, much horizontal contamination apparently also occurs, which may be based on memorized versions of the story rather than on manuscripts.

For lack of colophons and because no in-depth research has been done on the orthographic idiosyncrasies of manuscripts from Lombok, dating manuscripts is extremely difficult, and thus providing an historical sequence of the transmission process is virtually impossible. Deciding to edit the oldest manuscript is therefore impossible as well, as we cannot decide which one is the oldest. For the time being it would perhaps be best if we decide to edit the longest texts as those contain at least the most story information and decide later, when the stories demand more investigation, to delve into the diverging idiosyncrasies of individual and groups of manuscripts which are, after all, random remains of the total tradition of transmission and moreover randomly preserved in collections. In any case, the variants between manuscripts do provide tools for grouping them, as has become clear from the above and which the reader may glance from comparing the entire texts, which follow below. 


\section{The texts of the Nabi Aparas}

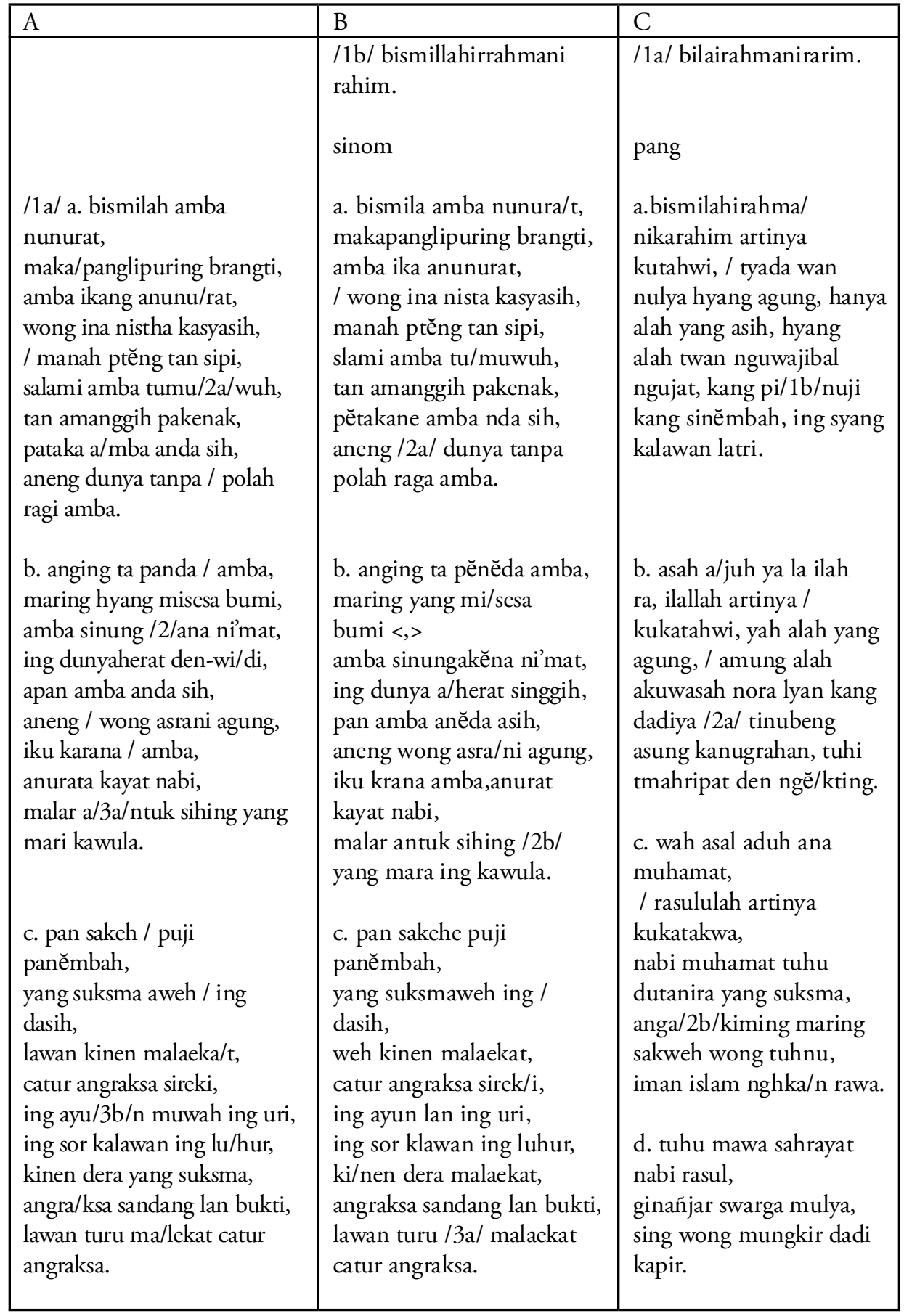


d. lah ta sami /4a/ pyarsakna, d. lah ta sami pyarsakna, sihing yang mara ing dasih, yan / patut ormatakna, sadaya kang ami/singgih, karana dunya iki, tan lawas apan sawěgung, nulih kinen ngambila, /4b/ hyang widi aken jabra'il, ing kana / sami wruh pramaning alah.

e. kewala / ambasung wikan, ing sakwehe sang / asudi, něda sami elingěna, wahyu/ $5 \mathrm{a} /$ nira sang yang widi, lawan wahyuning nabi, / rasululah kang linuhung, moga sih/ing aherat, lan sakeh nabi / lan wali, lawan mu'min kang aniksa $15 \mathrm{~b} /$ ing sinupar.

f. mogamba tan kěneng sa/ sar,

tan tablěteng tulya sari, a/mba anda sinampura, maring yang mise/sa bumi, kaping kalih ing nabi, utusa/ $6 \mathrm{a} / \mathrm{n}<\mathrm{n}>\mathrm{da}$ pitulung, nda brěkat sapa'at, / ing dunya ing $<$ a herat singgih, amba / anda dasihing yang kang ma'mulya. /

g. pan kula kinen amrĕna, carita andi/6b/ka nabi, wetning kula tan lěnggana, anga/wi kinen gupiti, nata pupuhe $\mathrm{i} / \mathrm{ki}$, tan rasa tan duk ingapus, / wong minda tan werruh basa, kdah aniru wong $/ 7 \mathrm{a} / \mathrm{lwih}$, cumantaka kadya wong utameng / sastra. sihing yang $\mathrm{ma} / \mathrm{ra}$ ing dasih, yan apatut ormatakna, sdaya kang sami / singgih, krana dunya iki, tan lawas pan suwagung, / nulih kinen ngambila, yang widi aken jabra'il, pan ing kana /3b/sami uruh pramaning alah.

e. kewala ambasung wikan, ing sakwe/he kang asudi, nda sami ilingěna, wahyunira yang wi/di, klawan wahyuning nabi, rasulullah kang linuhung, / moga sihing aherat, sakwehe nabi lan wali, lawan mu/4a/'min kang aniksa ing sikupar.

f. moga amba tan kěneng sasar, tan ka/blěteng tulya sari, amba nĕda sinampura, maring si/ra sang yang widi, kaping kalih ing nabi, utusan něda / pitulung, něda brakat sěpa’at, ing dunya aherat si/4b/ nggih amba nĕda sihing yang kang ma’mulya.

g. pan kula kinen amarna, / gitane andika nabi, wetning kula tan lěnggana, anga/wi kinen gupeti, nata pupuhe iki, tan rě/tut tan aduk ingapus, kadya wong minda tan wěruh ing basa, $\mathrm{kdah} / 5 \mathrm{a} /$ aniru wong luwih, cumantaka kadya wong ngutameng sastra. 


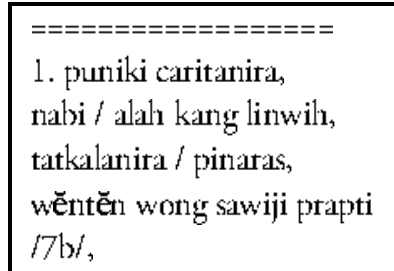

atataken rĕkeki,

datĕng bu ba/kar lingipum,

twan kadya puriapa,

t tatkala nabi linwili,

duk apra/ras amba taken

datĕnig twan.

2. sapa / 8 a/ sentĕrn kang

anaras,

lan sapa ikang / gupesi,

tatkala nabi apara/s,

lan dastare saking pundi,

miiswalı dintĕrn punapi,

lan purnapa

tawu/sb/nipur,

miwal tanggal ping pira,

lain punapa sasilnneki,

lawa/n pintĕn umure

tatkalapara/s.

3. mangkin tuwar

watanana,

bagi/ $/ d / a<a b u$

bakar angling,

tatkalanira pi/naras,

nabining yang kang

linvili,

ya / ta waliyun yang widi,

aprang kaflanipur,

duk musuli raja lakat,

$196 /$ ing desa mkali

nggreneki,

dina sne/n waktunira

kalaparas.
1. singgi/h puniki carita,

nabi alah kang linuwili,

tatkala nabi / aparas,

wĕntĕrn wong sawiji prapti,

matur pataken te/ki,

maring abu bakar

lingipur,

twan kadi punapa,

tatkala nabi linu/6a/wiln.

duk aparas amba taken

datĕng tuwan.

2. sapa sentĕı kangr amaras,

la/n sapa saksine malili, tatkala nabi aparas,

lan dastar/e saking pundi, miwali rawuly punapi, lan punapa tawuni/pur, miwah tanggal ping pira, lan punapa sasilnneki, lawa/6b/ne santĕn kelı rema nabi aparas.

3. mangkin tuwan wartanana,

bagi/nda abu

bakar angling,

duk tatkala nabi aparas,

nabining yang kang /

linuwili,

tatkalandika nabi, aprang sabil/puniku, duk musuh raja lahat, ing desa mĕkali nggeneki $17 \mathrm{a}$,

dina snen waktunita kalaparas.
1. ana mangke kawarna, cari/3a/tane andika nabi wali, tatkalanira acukur, I anda wong sawiji prapta, atur pataken maring abu bakar lingipur, lah twan ka/di punapa, tatkala nabi linuwiln.

2. duk <k>alani/3b/ra aparas, nabi alalı punika rĕke sunta/keninl, sapa sentĕn kang añukur, lan $s a / p a$ saksineka, tatkala andika nabi a/cukur, lan dastare iku apa, ing mangke rawuli / $/ 4$ / punapi.

3. lan punapa tawuneka, myali tanggal ping / pira sasilineki,

lawan kelie remanipun, mangke twan warta amba, den-lingi/ta bagindabu bakar amuwus, duk $<k>$ la nabi $a / 4 b / p a r a s$, nabinita yang linuwil.

4. tatkalani/ta aprang, sabilulah ing desa mĕkalı ë/nggoneki,

dina snen waktunipun, tatka/lanita aprasas, davĕgita maca kroluu /5a nabi rasul,

nulya jabrail prapta, anbakta / ayat puniki. 


\begin{tabular}{|c|c|c|}
\hline $\begin{array}{l}\text { 6. jabra'il aris } \\
\text { and } 1 \text { lb/bda, } \\
\text { mangkin ngong matur } \\
\text { ring widi, tumulya / } \\
\text { jabra'il mangkat, } \\
\text { matur ring yang } \\
\text { ma'a/tinggi, } \\
\text { tan dangu aneng margi, } \\
\text { sakde/p netra arawuli, } \\
\text { ing ayunan yang } \\
\text { mano/ } 12 a / \text { n, } \\
\text { matur ring yang } \\
\text { ma'atinggi, } \\
\text { ing sasili / punatpa nabi } \\
\text { tuwan pinatas. / }\end{array}$ & 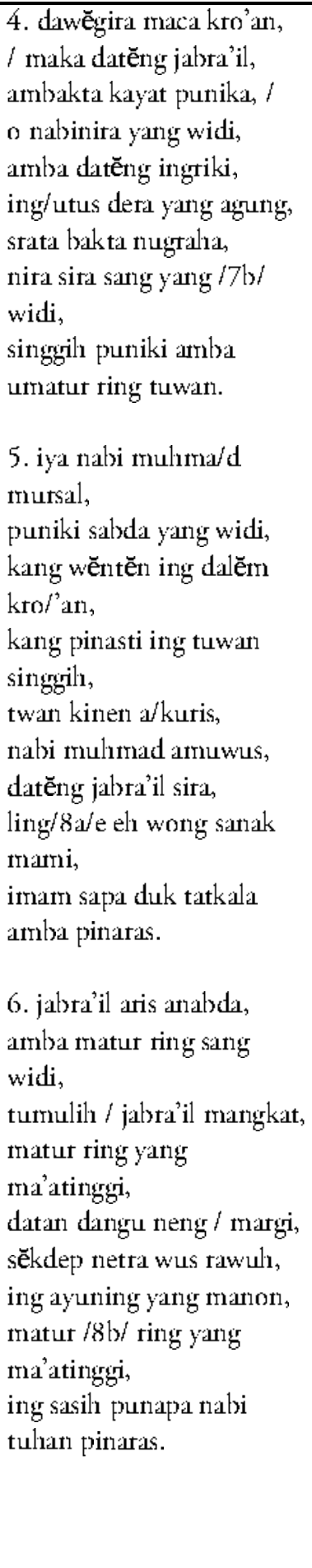 & 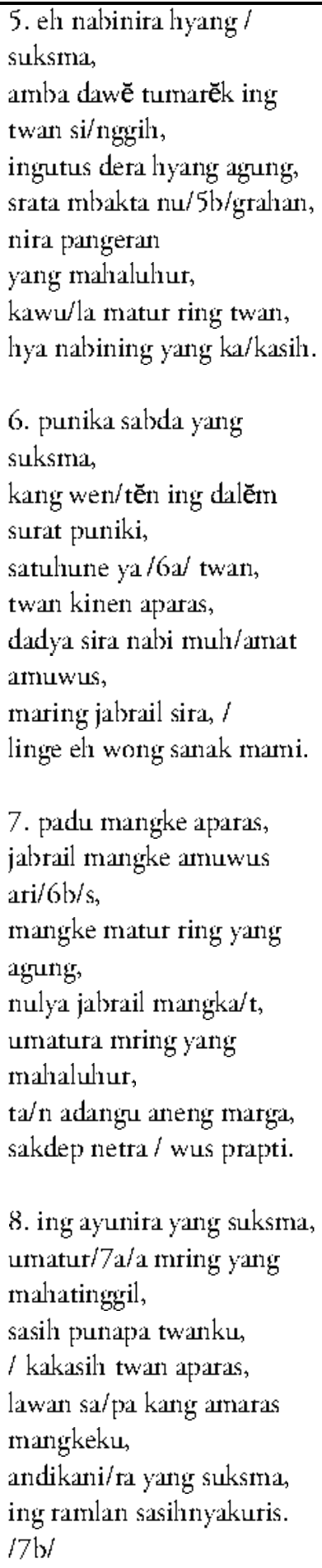 \\
\hline
\end{tabular}




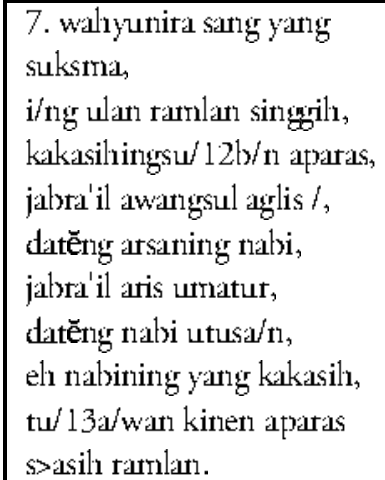

8. nabi / mulamad anabda,

datěng jabra' il si/nggilı, tatkala amba pinaras,

f ing arsane sapa iki, jabra'il si/ $13 b / g r a l$ aglis, punika tumulya matur, /

/ datĕng ing sang yang manon,

sulsal anulya prapti, datan daingu prapta ing nabi utusan.

9. lingi/ $14 a /$ ta jabra' il mojar,

hya nabining yang /

kakasill,

paran ta arsaning twan,

/ karana twan pribadi, wrul namaning/hyang widi,

tanlyan tuwan kang wruli,

maka /14b/ nabi ngandika, eln jabrail dan lingneki,

dastar amba yen sampu/n la paras puriata.
7. wathyuning yang suksma,

ing ulan ramlan singgili,

kakasihing/sum aparas,

jabrail wangsul aglis,

datĕng arsa/ning nabi,

jabrail aris wmatur,

nĕlıĕring nabi mulıamad,

e/9a/h nabining hyang

kakasili,

tuwan kinen aparas sasil

ramlan.

8. nabi / mulnmad anabda, tkeng jabta' il singgili,

tatkala amba pinara/s, ing arsane sapa iki,

jabrail nulyaglis, pu/nika tumulya matur,

datĕng ing yang manon, sasa'at mulya prapti, $/ 9$ bf datan dangu prapta ing nabi utusan.

9. nhleĕr jabra'il mojar, ya nabining yang /

kakasili,

aparas sarsaning calnya, krana twan pribadi,

/ wrul namaning yang widi,

tan liyan tuwan kang wruli,

mangkana ing/andika, eh jabra il lingneki,

dastar amba yan sampun apa/10a/tas punatpa.
9. sira mangke kang anaras, jabrail sigraln si/ra lumaris, jabrail anulya w/matur, maring nabi mulamat, eh / nabining yang mangke andikacukur,

mangke ing $/ 8 \mathrm{a} /$ bulan ramlan,

nabi mulamat lingrya aris.

10. mara ing jabrail sira,

tatkalane / amba aparas mangkin,

ing arsane / sapa iku, jabrail malilı matura, kadi pa/8b/wkasira, sakdep netra wius prapti.

11. tan adange/malih prapta,

ing ayunita nabi/

mutsalim,

lingira jabrail matur,

f mara ing nabi muliamat, twan aparas arẹpa $/ 9 \mathrm{~d}$ nutcalya iku,

krana twan pribadya, wĕrula / nama yang pribadi.

12. tan liyan tuwan kang / wikan,

samangkana andikaning yang/widi,

eh jabrail purapeku,

dadi $/ 9 \mathrm{~b} / \mathrm{dastat}$ kawula, yer kawula sampur aparas mangke/ku,

nulya jabrail mangkat, matur ring $y$ ang /

mahatingi. 


\begin{tabular}{|c|c|c|}
\hline 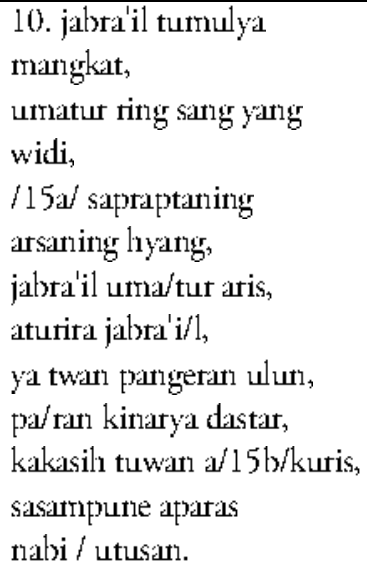 & $\begin{array}{l}\text { 10. jabrail tumulya } \\
\text { mangkat, } \\
\text { umatur ring yang widi, } \\
\text { sa/prapta ing arsaning } \\
\text { yang, } \\
\text { jabra il umatur ratis, } \\
\text { atur/ira jabra il, } \\
\text { ya tulian pangeran kang } \\
\text { agung, } \\
\text { pa/ran kinarya dastar, } \\
\text { kakasiln tulian akuris, } \\
\text { sasampune a } 10 \text { b/paras } \\
\text { nabi utusan. }\end{array}$ & 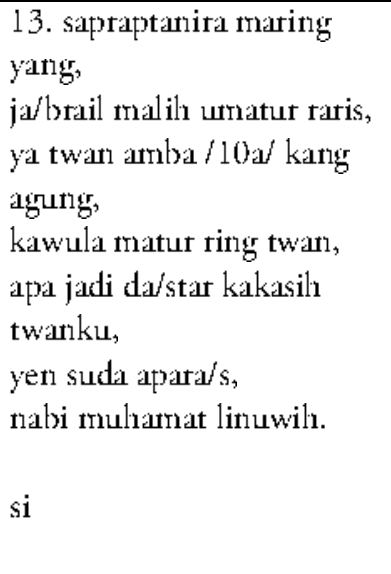 \\
\hline 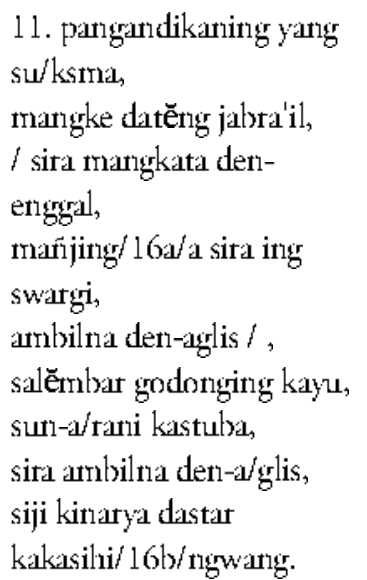 & $\begin{array}{l}\text { 11. angandika yang } \\
\text { suksma, } \\
\text { mangke da/tĕng jabrail, } \\
\text { sira mangkata den-enggal, } \\
\text { manjing/a sira ing swargi, } \\
\text { ambilërn den-aglis, } \\
\text { salĕmbar / godonging } \\
\text { kayu, } \\
\text { ingsun aranin kastuba, } \\
\text { sira ambil de/lla/n-aglis, } \\
\text { siji kinaryanĕn dastar } \\
\text { kakasilningwang. }\end{array}$ & $\begin{array}{l}\text { 14. wĕn tĕn pramaning yang } \\
\text { suksma, } \\
\text { mangke / lob/ maring } \\
\text { jabrail, } \\
\text { sira mangkata den-enggal, } \\
\text { / angannbil sireki, } \\
\text { marnjinga maring swatgadi, } \\
\text { salĕrnbar godonging kayuli, } \\
\text { / godongepun kastuba, } \\
\text { lah annbila depu/ } 1 \text { la/n- } \\
\text { aglis, } \\
\text { mung salĕmbar iku kangr } \\
\text { karyanĕn dastar. }\end{array}$ \\
\hline 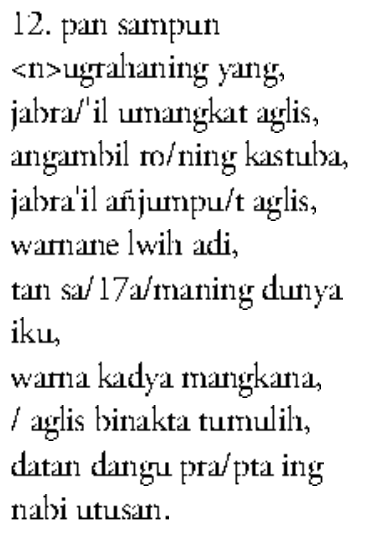 & 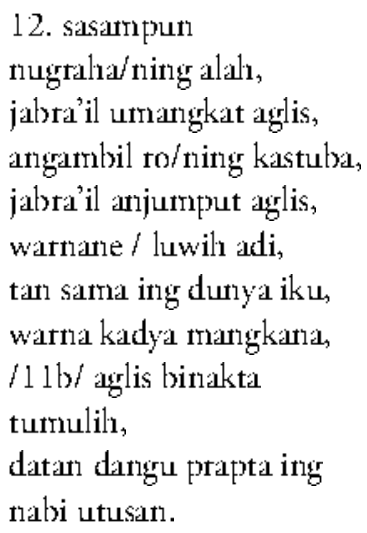 & $\begin{array}{l}\text { 15. pan saking nugralianing } \\
\text { yang, } \\
\text { jabrai/l mangat aglis, } \\
\text { angambil moning kastu/ba, } \\
\text { mangke inganbil tumulil, } \\
\text { warnane lë/ wilı adi, } \\
\text { saking wannane kangr kaywl, } \\
\text { tidalı a/da samanya, } \\
\text { aglis binakta tumulili, } \\
\text { f tidalı lama wus dateng } \\
\text { nabi utusan. }\end{array}$ \\
\hline
\end{tabular}




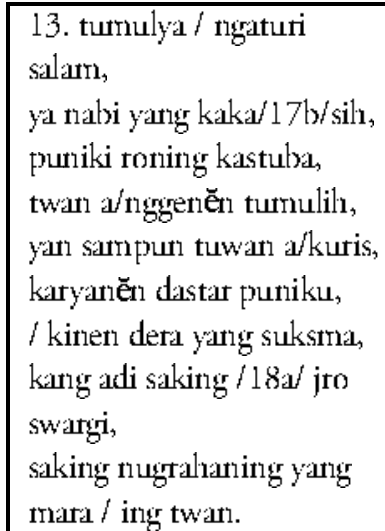

14. lingita nabi utusan,

/ mangke datěng jabra'il, sapa kang / amaras amba, jabra' il umatur aris, flob/ saking nugralnaning widi,

amba kang kine/n anukur, mangke datĕng ing twan,

/ dening yang kang ma'atinggi,

twmu/lya glis nabi utusan pinaras.

15. ta/19a/tkalanita piriaras,

nabi dening jabraf'il, dawĕ̀ sangang wlas dina, ing ula/n ramlan singgili, ing snen dinaneki,

/ tumulya nigabakti sarnpur,

mangke samya/19b/

tuningal,

tatkala nabi akuris,

/ kapĕnĕtan sadaya samya tuminga $/$, tatkala nabi

akuris, / kapĕnĕtan sadaya samrya tumingal.
13. tw/mulya ngaturing
salam,
hya nabining yang kakasili,
puni/ki roning kastuba,

twan anggeně̀n tumulilı,

yan safmpun tuwan akuris,

karyanĕrn dastar puniku,

kinen dera yang/12a

suksma,

kang adi saking swargi,

saking nugralianing yang

datĕng twan.

14. ta/tkalanira pinaras, nabi dening jabra'il,

dawĕg sa/nga wĕlas dina, ing ulan ramlan singgilu,

ing snen dinaneki /,

tumulya ngĕbakti sampun, mangke samya tuningal, ta/ $12 \mathrm{a} / \mathrm{tkalanira}$ akuris, kapĕnĕdan sdaya sami tumingal. /
16. sampun sira asung salam, hya nabi $y$ ha $/ 12 \mathrm{~d} /$ saidin, inilah dawur kastuba, twanku a/mamakeh iki, yen tuwan suda a/kuris, dibuwat sorban tuwanku, salking pangkon yang suksma, pakweln saking swargadi, 112 b/ krana tya alali kapada twan.

17. sapdana nabi muli/amat,

datĕng sira jabrail, sapa / kang manguris amba, jabrail <l>ingrya ari/s, saking pangkon yang widi, amba disurula a/ $13 \mathrm{a} /$ ruktur, datĕng kepada twan, denira yang malia/tinggi, dadyaglis nabi mulamat pi/naras.

18. tatkala aparas, nabi dening jabrail, dawĕg sangang whas di/ 13 b/na,

ring sasili ramlan singgilı, ring snen dinaneki,

a/nulya sĕmbaliyang iku, rong rekaliat a/salan, pratingkah nabi akuris, kapětnĕdan sadaya sami tumingal. 


\begin{tabular}{|c|c|c|}
\hline 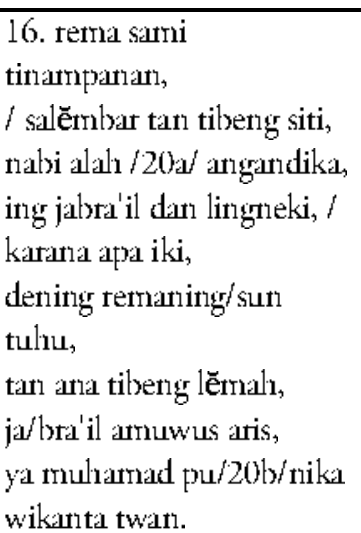 & $\begin{array}{l}\text { 15. rema sanni } \\
\text { tinampanan, } \\
\text { salëmbar tan tibeng siti, } \\
\text { nabi / mangke angandika, } \\
\text { ing jabra'il dan lingneki, } \\
\text { krana a/pa iki, } \\
\text { dening remaningsun tuliu, } \\
\text { tan ana tibeng lëmali, } \\
\text { /13a/ jabra'il amuwus aris, } \\
\text { ya muhmad puniki } \\
\text { wikanta twan. }\end{array}$ & 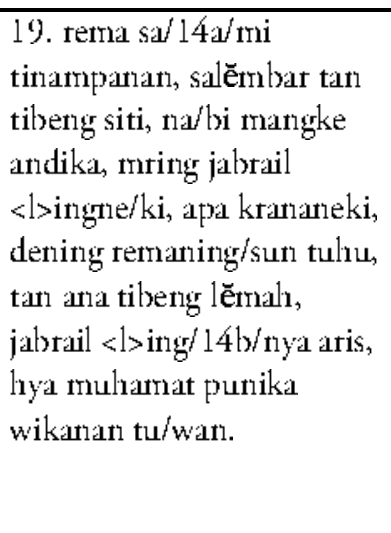 \\
\hline $\begin{array}{l}\text { 17. mulane tan ti/beng } \\
\text { lëmali, } \\
\text { mangkin tena twan } \\
\text { singgil, / } \\
\text { dene sanni tinampanan, } \\
\text { de/ne sakweh widadari, } \\
\text { nabi annuwu/2la/s aris, } \\
\text { pira kelhe remaningsun /, } \\
\text { jabrail angandika, } \\
\text { kehe / rema twan } \\
\text { mangkin, } \\
\text { sakëti ti/gang laksa lan } \\
\text { tigang nambang. }\end{array}$ & $\begin{array}{l}\text { 16. mu/lane tan tibeng } \\
\text { lĕmali, } \\
\text { mangke rema twan } \\
\text { singgilı, } \\
\text { dene / sani tinampanan, } \\
\text { denings sakwelı widadari, } \\
\text { nabi a/muwus aris, } \\
\text { pira kelne renaningsun, } \\
\text { jabra il anga/ } 13 \text { b/ndika, } \\
\text { kehe rema twan mangkin, } \\
\text { sĕkĕti tigang laksa la/n } \\
\text { tigang nambar. }\end{array}$ & 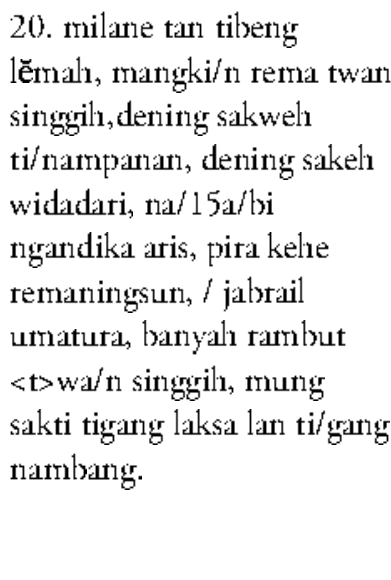 \\
\hline 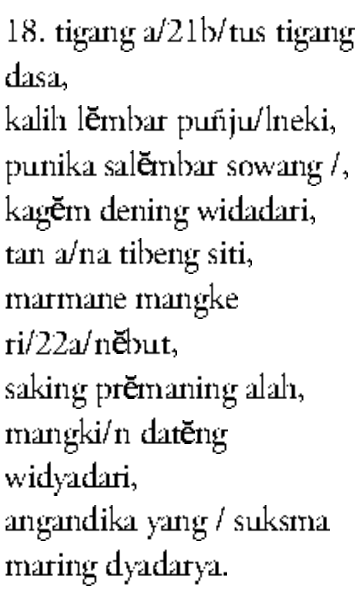 & $\begin{array}{l}\text { 17. tigang atus tigang dasa, } \\
\text { kalih lëmbar puriju/neki, } \\
\text { punika sasalĕmbar swang, } \\
\text { kagĕmn dening bidada/ri, } \\
\text { tan a tibeng siti, } \\
\text { remane sanni rinĕbut, } \\
\text { saking / } 140 / \text { pramaningr } \\
\text { alah, } \\
\text { mangkin datĕng widadari, } \\
\text { angandika yang suksma } \\
\text { maring/ widadari. }\end{array}$ & $\begin{array}{l}\text { 21. tigang atus tigang dasa, } \\
\text { tigang lëmbat } / 15 \text { b/ } \\
\text { putusneki, punika saĕmbar } \\
\text { sowang, kagĕ/n dening } \\
\text { widadari, tan ana tibeng } \\
\text { si/ti, manmane sami } \\
\text { rinĕmbut, saking } \\
\text { pra/nnaning alali, ingandika } \\
\text { widadari, dening a/ } 16 a / l a h \\
\text { pangreran yang maliamulya. }\end{array}$ \\
\hline
\end{tabular}




\begin{tabular}{|c|c|c|}
\hline 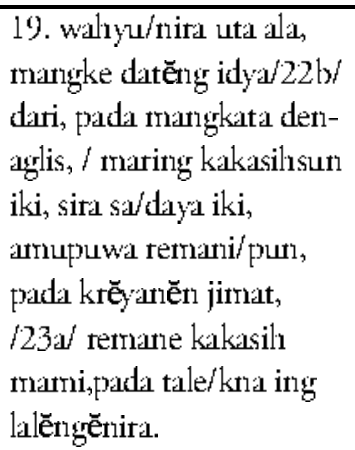 & 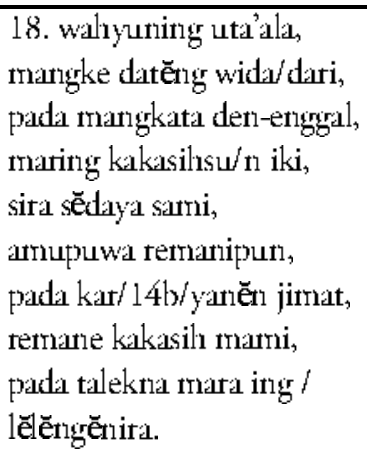 & $\begin{array}{l}\text { 22. prananing yang } \\
\text { maha/mulya, mangke } \\
\text { maring widadari, sira } \\
\text { mangka/ta den-enggal, } \\
\text { maring kakasilısun iki, sira } \\
\text { lunga ta sami, amupuwa } \\
\text { rema/ l6b/nipum, pada } \\
\text { karyanĕn simat, remane } \\
\text { ka/kasilı manni, pada } \\
\text { talekna maring lalĕngenira. }\end{array}$ \\
\hline 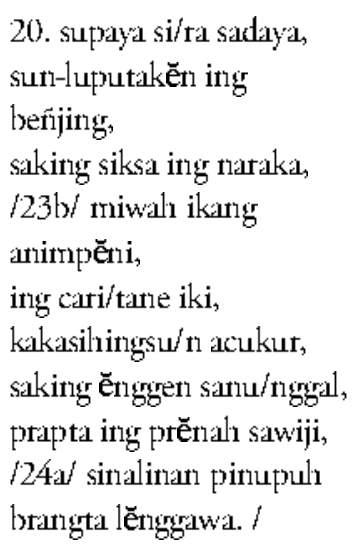 & 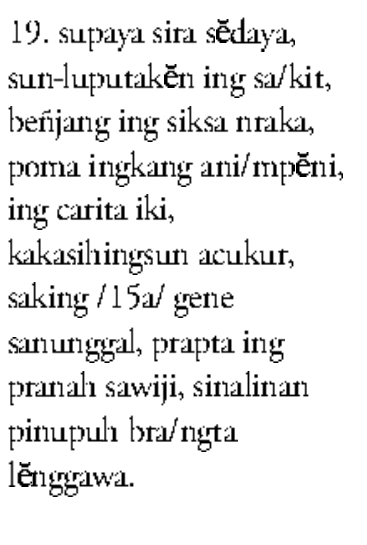 & $\begin{array}{l}\text { 23. supaya sira sadaya, } \\
\text { sun-luputaken ing penyakit, } \\
\text { saking ing api nitaka, } \\
/ 17 \text { a pona sing sapa } \\
\text { nimpenin, } \\
\text { maring carita puniki, / } \\
\text { kakasilningsun acukur, } \\
\text { saking ĕnggenfe sanunggal, } \\
\text { sun-luputaken ing penyakit. } \\
\text { maring sira kang arep } \\
\text { animpena punika. /17b/ }\end{array}$ \\
\hline asmaradana & striat & smatan \\
\hline 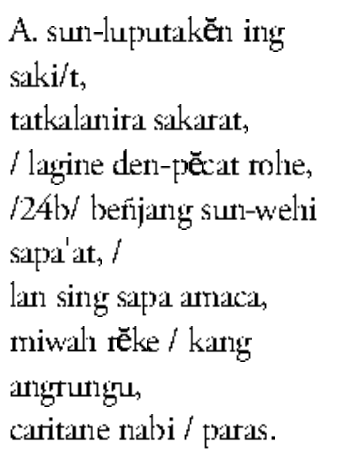 & 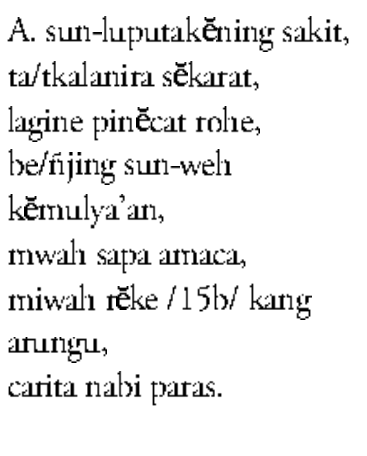 & $\begin{array}{l}\text { A. sun-luputaken ing } \\
\text { penya/kit, } \\
\text { tatkalanira sakarat, / } \\
\text { tatkala pinarcat rohe, } \\
\text { berijang sun-weln sapaat, } \\
\text { lan sing sapa annaca, } \\
\text { /18a/ niwah satkweln kang } \\
\text { arungu, } \\
\text { carita nabi aparas. }\end{array}$ \\
\hline $\begin{array}{l}\text { B. miwaln rĕke kang } \\
\text { anu/25a/lis, } \\
\text { atawa kang andrabeya, } \\
\text { dya/naning lyan bae, } \\
\text { mwaln rĕke kang/ } \\
\text { anbakta, }\end{array}$ & $\begin{array}{l}\text { B. miwaln rĕke kang anulis, } \\
\text { atawa/ kang andrabeya, } \\
\text { dyan ana ing lyane, } \\
\text { mwaln rĕke kang annba/kta, } \\
\text { ing carita punika, } \\
\text { kakasilningsun acukur, }\end{array}$ & $\begin{array}{l}\text { B. niwaln rĕke kang anulis, } \\
\text { / utawi kang andarbyeye } \\
\text { dyana / ing lyane, } \\
\text { niwali rĕke kang } \\
\text { nganbakta, } \\
\text { nning ca/ } 18 \text { b/rita punika, }\end{array}$ \\
\hline
\end{tabular}




\begin{tabular}{|c|c|c|}
\hline $\begin{array}{l}\text { ing carita punika, } \\
/ \text { kakasilningsun acukwr, } \\
\text { maka sun-weln } 25 \text { b/i } \\
\text { kanulyan. }\end{array}$ & ma/ka sun-weln ing sĕda'at. & $\begin{array}{l}\text { kakasilningsum acukur, } \\
\text { maka sun-weln / kamulyan. }\end{array}$ \\
\hline 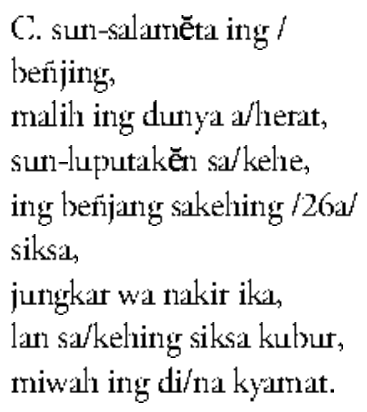 & 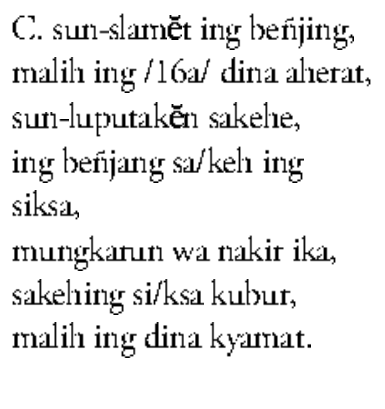 & $\begin{array}{l}\text { C. sun-salanataken sani, } \\
\text { dari dunya sampe ing } \\
\text { aherat, } \\
\text { sun-lu/put sakalyane, } \\
\text { ing benijang saking ing siksa, } \\
\text { /19a/ mungkarun wa } \\
\text { nakirun ika, } \\
\text { lan sakelie siksa kubur, } \\
\text { miwaln ing dina kyanat. }\end{array}$ \\
\hline 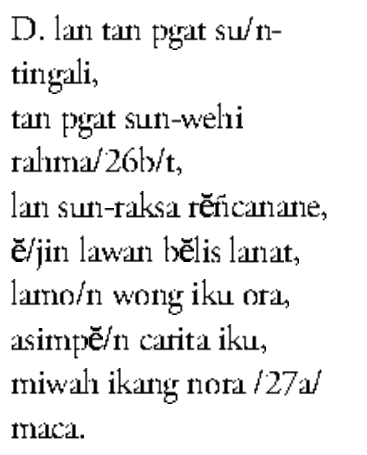 & 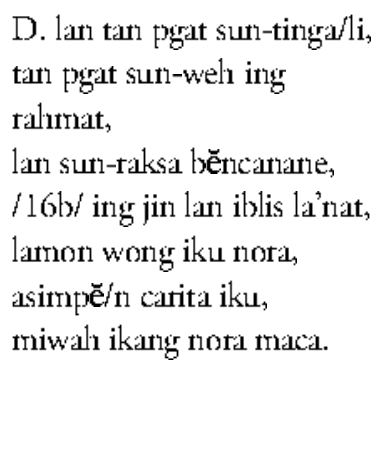 & $\begin{array}{l}\text { D. lan tan pgat sun-ti/ngali, } \\
\text { miwali tan pgat sun-weli } \\
\text { rahmat, } \\
\text { / lan sun-taksa bĕricanane, } \\
\text { jang/ kalawan bĕlis } \\
\text { lana/19b/t, } \\
\text { lanun wong iku nora, } \\
\text { animpen carita iku, } \\
\text { / lan tidalı mawu anaca, } \\
\text { lan tidaln mawu anaca. }\end{array}$ \\
\hline $\begin{array}{l}\text { E. miwali kang nota } \\
\text { ngupani, } \\
\text { miwali / kang nota } \\
\text { myarsa, } \\
\text { maka dadi wong } \\
\text { mu/napek, } \\
\text { asingit ingsun kaliwa/t, } \\
\text { lah poma engĕtna, } \\
\text { sira surn-weln/27b/i raliayu, } \\
\text { adoln saking duka cipta. / }\end{array}$ & $\begin{array}{l}\text { E. mwali kang no/ta } \\
\text { ngupani, } \\
\text { niwali kang nora myarsa, } \\
\text { maka dadi wong mu/napek, } \\
\text { asingid ingsun kalinat, } \\
\text { lah pona ingĕtna, } \\
\text { t17a sita sun-welni raliayu, } \\
\text { adoln saking duka cipta. }\end{array}$ & $\begin{array}{l}\text { E. lan ora pracaya malil, } \\
\text { mivalı ta/n arĕp miyarsa, } \\
\text { pasti iku wong munapek, } \\
\text { asĕngi/20/t ingsun } \\
\text { kalintang, } \\
\text { lannun wong ngingitna, } \\
\text { hya iku sun-weln rali/ayu, } \\
\text { aduln saking duka cipta. }\end{array}$ \\
\hline 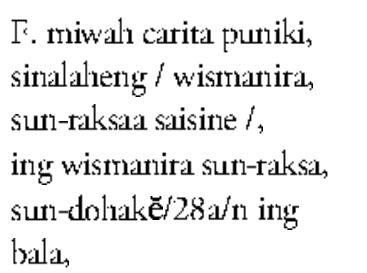 & $\begin{array}{l}\text { F. miwah ca/rita puniki, } \\
\text { saleh aneng wismanita, } \\
\text { sun-raksa/ saisine, } \\
\text { ing wismanira sun-taksa, } \\
\text { sun-adohakn ing bala, } \\
\text { ing slanine tumuwul, }\end{array}$ & $\begin{array}{l}\text { T. miwal carita puniki, } \\
\text { simpĕna neng wismanira, } \\
\text { sun-rak/sanĕn saisine, } \\
\text { wismanira sun-taksad, } \\
\text { adoli/20b/akĕn ing baliya, } \\
\text { angsal apitan tumuwul, }\end{array}$ \\
\hline
\end{tabular}




\begin{tabular}{|c|c|c|}
\hline $\begin{array}{l}\text { ing salanine tumūwūl, } \\
\text { ing tir/ta lawan pawaka. }\end{array}$ & $\begin{array}{l}\text { ing tirta lawan pawaka } \\
117 \mathrm{~b} \text {. }\end{array}$ & gni padĕm dening / tirta. \\
\hline 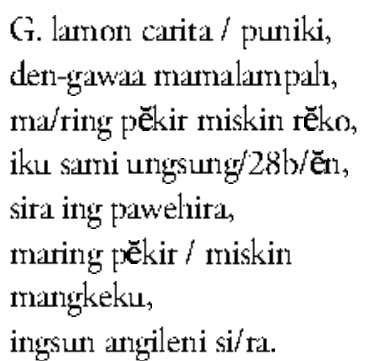 & 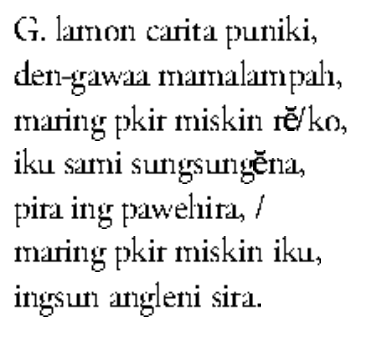 & $\begin{array}{l}\text { G. lamun carita puniki, } \\
\text { ginawa atkan malampal, } \\
\text { mnring pĕkir miskin rĕko, } \\
\text { iku sami sungsungĕn, } \\
\text { pirang ing pawelnira, } \\
\text { mnring pĕkir miskin iku } \\
121 \text { ingsum angilen ing } \\
\text { sira. }\end{array}$ \\
\hline $\begin{array}{l}\text { H. upana anta sadĕmi, } \\
\text { sun-ile/ni pitung dasa, } \\
\text { saking punika pawelie, } \\
129 \text { / saking kudrating } \\
\text { yang suksma, } \\
\text { mangkana walifyun alah, } \\
\text { pinasti antuk raliayu, } \\
\text { / sakelne kang angupana. }\end{array}$ & $\begin{array}{l}\text { H. upanna at/ta sadmi, } \\
\text { sun-ileni pitung dasa, } \\
\text { saking punika pawelie, } \\
/ 18 \text { a saking kudrating yang } \\
\text { suksma, } \\
\text { mangkana waliyun alali, } \\
\text { pinasti antuk raliayu/, } \\
\text { saking kang angupana. }\end{array}$ & $\begin{array}{l}\text { H. upana arta sadĕmin, } \\
\text { / sun-ilen ing pitung laksa, } \\
\text { saking pundi kang pawelne, } \\
\text { saking kudrat yang suksma, } \\
\text { mangkana sabdaning dali, } \\
\text { kang pinantah anukrali ayu, } \\
121 \text { b/ sakelne ingkang } \\
\text { utama. }\end{array}$ \\
\hline 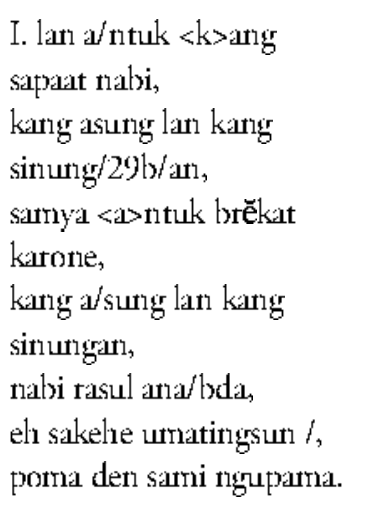 & $\begin{array}{l}\text { I. lan antuk sapa'at nabi, } \\
\text { kang asung lan } \\
\text { ka/sinungan, } \\
\text { sannya antuk brakat katone, } \\
\text { kang asung la/n } \\
\text { kasinungan, } \\
\text { nabi rasul anabda, } \\
\text { eln sakwehe umatingsun, } \\
\text { hob/ moga ta sira } \\
\text { ngupana. }\end{array}$ & $\begin{array}{l}\text { I. lan atuk apaa/t nabi, } \\
\text { kang asung lan sasinungan, } \\
\text { sa/mya antuk brakat katone, } \\
\text { kang asung la/n sasinungan, } \\
\text { nabi rasul anapda, } \\
\text { ilingĕna } / 22 \mathrm{a} \text { ujaringsun, } \\
\text { poma den sanni pracaya. }\end{array}$ \\
\hline 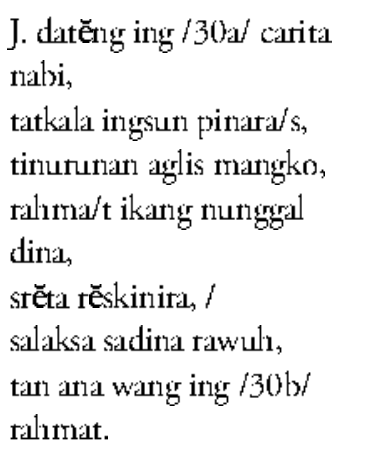 & $\begin{array}{l}\text { J. datĕng ing caritaning } \\
\text { nabi, } \\
\text { tatkalanira pinara/s, } \\
\text { tinumunan aglis mangko, } \\
\text { ralimating nunggal dina, } \\
\text { stata ra/skinita, } \\
\text { slaksa sadina rawuli, } \\
\text { tanana tuwang ing } \\
\text { ralima/t. }\end{array}$ & $\begin{array}{l}\text { J. da/tĕng ing carita nabi, } \\
\text { tatkalaniina aparas, } \\
\text { katumunan aglis mangko, } \\
\text { ramet ika tunggal dina, } \\
\text { arta lan mi/22b/skinita, } \\
\text { tan pgat sadina rawuli, } \\
\text { tan ana tuwang/ing ralinat. }\end{array}$ \\
\hline
\end{tabular}




\begin{tabular}{|c|c|c|}
\hline $\begin{array}{l}\text { K. minali rinaksa sireki, } \\
\text { sakeln ikang kni ala, } \\
\text { miwali durja/na sakabeli, } \\
\text { lan adoli saking sa/salat, } \\
\text { lamon sira alara, } \\
\text { agri/3la/sa antuk pitulung, } \\
\text { tur rĕke ta aglis wa/ras. }\end{array}$ & $\begin{array}{l}\text { K. miwall carita puniki, } \\
\text { sakehe kang kĕri ala, } \\
\text { miwal durja/ } 19 \text { a na } \\
\text { sĕkabeh, } \\
\text { lan adoli saking sasalat, } \\
\text { lamon sita alara, } \\
\text { a/glis antuk pitulung, } \\
\text { tur rĕke aglis waras. }\end{array}$ & 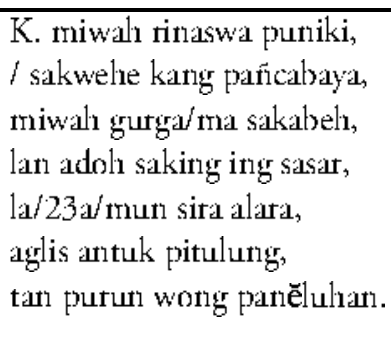 \\
\hline $\begin{array}{l}\text { L. yen binakta cariteki, } \\
\text { i/kang apringga punika, } \\
\text { ikang akeln / durbiksane, } \\
\text { miwaln sakeh sato } 3 \mathrm{lb} \text { b } \\
\text { galak, } \\
\text { tan and myatana, } \\
\text { lanon bi/nakta ing lawut, } \\
\text { caritaningsu/n aparas. }\end{array}$ & $\begin{array}{l}\text { L. yan binakta / carita iki, } \\
\text { ing katang pringga punika, } \\
\text { ikang akeln dur/biksane, } \\
\text { miwali sakweln sato galak, } \\
\text { tan ana anyatna / } 19 \text { b/ } \\
\text { lanon binakta maring } \\
\text { lawut, } \\
\text { caritaningsum aparas. }\end{array}$ & $\begin{array}{l}\text { L. yan ginawe jima/t iki, } \\
\text { ing karang pringga punika, } \\
\text { ingkang a/kel durbik } \\
\text { mangko, } \\
\text { miwall sakweh sato } \\
\text { ga/23b/lak, } \\
\text { pada ajrili sadaya, } \\
\text { lamun binakta ing la/mut, } \\
\text { carita nabi aparas. }\end{array}$ \\
\hline $\begin{array}{l}\text { M. nnina kang aneng } \\
\text { jala/dri, } \\
\text { miwali mina kang agalak, } \\
\text { dadi /32a/ sanni ajrilı } \\
\text { kabeli, } \\
\text { bajul tan wani pa/rëka, } \\
\text { miwah lanon alayar,/ } \\
\text { raluyu tur aglis rawuli, } \\
\text { saking / sawabe carita. }\end{array}$ & $\begin{array}{l}\text { M. mina kang a/neng } \\
\text { jaladri, } \\
\text { mwali mina kang agalak, } \\
\text { iku dya ajrilı skabeh, } \\
\text { bajul lan wani parĕka, } \\
\text { miwal lamon alayar, } \\
\text { ra/hayu tur aglis rawul, } \\
\text { saking sawabe carita. }\end{array}$ & $\begin{array}{l}\text { M. mina / kang aneng } \\
\text { jaladri, } \\
\text { sima sagung mina kang/ } \\
\text { galak, } \\
\text { pada jrilı sakabehe, } \\
\text { datan pu/ } 24 a / \text { nun umarĕka, } \\
\text { miwalı lamon alayar, } \\
\text { raliayu / tur aglis rawuli, } \\
\text { saking sawabing carita. }\end{array}$ \\
\hline $\begin{array}{l}\text { N. lamon binakta } \\
\text { a } 32 \text { b/jurit, } \\
\text { sakelne sarijata sima, } \\
\text { bdil wawos pdang towok/, } \\
\text { tan and anyatana, } \\
\text { tur kuwa/t yudanita, } \\
\text { saking ralinating yang } \\
\text { agung, } \\
\text { /33a/ kang annbakta ing } \\
\text { carita. }\end{array}$ & $\begin{array}{l}\text { N. lamon bi/20a/nakta } \\
\text { ajurit, } \\
\text { kabehe sĕrijata sinna, } \\
\text { bdil wawuli pdang towok, / } \\
\text { tan and amyatna, } \\
\text { tur kwat payudanita, } \\
\text { saking talinnating / yang } \\
\text { agung, } \\
\text { kang ambakta ing carita. }\end{array}$ & $\begin{array}{l}\text { N. lamon binakta ajurit, } \\
\text { sakwehe / sanjata sima, } \\
\text { bedil wawos pdang towok, } \\
\text { /24b/ tan andamyatna, } \\
\text { tur kuwat payudanita, } \\
\text { saking nu/gralian yang } \\
\text { agung, } \\
\text { miwal kang bakta carita. }\end{array}$ \\
\hline $\begin{array}{l}\text { O. lamon ana krĕ/yaneki, } \\
\text { atawa agagaweya/n, } \\
\text { iku aglis dadi rĕko, }\end{array}$ & $\begin{array}{l}\text { O. lamon ana karyane/ki, } \\
\text { atawa agagaweyan, } \\
\text { iku aglis dadi mangko, }\end{array}$ & $\begin{array}{l}\text { O. lamon ana karyaneki, } \\
\text { utawi a/gagawyen, } \\
\text { iku dadi glis mangko, }\end{array}$ \\
\hline
\end{tabular}




\begin{tabular}{|c|c|c|}
\hline $\begin{array}{l}\text { /lawan malili wong } \\
\text { punika, } \\
\text { atsatali /33b/ wong kang } \\
\text { whas, } \\
\text { tan kĕna bĕnduning tatu/, } \\
\text { angawiula kinasyan. }\end{array}$ & $\begin{array}{l}\text { lawan ma/20b/lih wong } \\
\text { punika, } \\
\text { akatalı wong kang wlas, } \\
\text { tan kĕna bĕnduning ratu, } \\
\text { anga/ wula kinasyan. }\end{array}$ & $\begin{array}{l}\text { yang manggilı } / 25 \text { a rĕke } \\
\text { ralianja, } \\
\text { akatalı wong kang awlas, } \\
\text { tan kë/na binĕndon ing } \\
\text { ratu, } \\
\text { tan kawula kinasilı/an. }\end{array}$ \\
\hline $\begin{array}{l}\text { P. lan malil / benjang yen } \\
\text { mati, } \\
\text { tan kĕna ing / marga sasar, } \\
\text { wong iku said pati/34a/ne, } \\
\text { ikang anggadulu carita, } \\
\text { nabi ta/tkalaparas, } \\
\text { kalintang sawabe / agung, } \\
\text { saking ralmating yang } \\
\text { suksma. }\end{array}$ & $\begin{array}{l}\text { P. lan malil berijang yen } \\
\text { mati, tan kĕna / ing marga } \\
\text { sasar, wong iku said patine, } \\
\text { ikang agadula / carita, } \\
\text { nabi tatkalaparas, } \\
\text { kĕlinitang sawabe agung, } \\
\text { saking / } 2 \text { la ralinnating } \\
\text { yang suksma. }\end{array}$ & $\begin{array}{l}\text { P. lan malih enjang yen } \\
\text { mati, } \\
\text { tann ma/nggih matga sasar, } \\
\text { wong ika sait patine, } \\
\text { ikang } 25 \text { b/anggawa carita, } \\
\text { nabi tatkala aparas, } \\
\text { kali/ntang sawabe agung, } \\
\text { kakasiln ing yang nabi } \\
\text { muliamat. }\end{array}$ \\
\hline 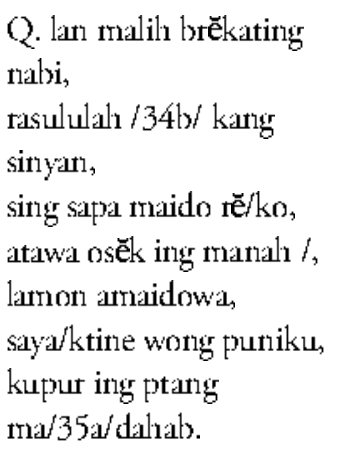 & $\begin{array}{l}\text { Q. lan malilı brakating } \\
\text { nabi, rasulullalı kang } \\
\text { sinya/n, sing sapya maido } \\
\text { rĕko, atawa osĕk ing / } \\
\text { manali, lamon ana } \\
\text { maidowa, sayaktine nong / } \\
\text { puniku, kupuring pĕtang } \\
\text { mĕdaliab. }\end{array}$ & $\begin{array}{l}\text { Q. lan malih brakat ing } \\
\text { nabi, } \\
\text { rasululah kang sinadyan, } \\
\text { sing sapa maido rĕko, } \\
126 a / \text { yen osik ing manale, } \\
\text { lamon ana maidot, } \\
\text { sayaktine wong puniku, } \\
\text { pasti manggig mar/ga papa. }\end{array}$ \\
\hline
\end{tabular}




\section{Bibliography}

Behrend, T.E.

1987 The Serat Jatiswara; Structure and Change in a Javanese Poem 1600-1930. $\mathrm{PhD}$ thesis, Australian National University.

Budiwanti, Erni

2000 Islam Sasak. Wetu Telu Versus Waktu Lima. Yogyakarta: LKiS.

Carey, Peter

2008 The power of prophesy. Prince Dipanagara and the end of an old order in Java, 1785-1855. Leiden: KITLV Press.

Eerde, J.C. van

1906 'De Toetoer Monyèh op Lombok', Bijdragen tot de Taal-, Land-en Volkenkunde 59, 17-109.

1913 'De Toetoer Tjilinaya op Lombok', Bijdragen tot de Taal,, Land-en Volkenkunde 67, 22-59.

Jacq, Pascale

1998 'How Many Dialects are There?', in: Peter K. Austin and Herman Suheri (eds) Sasak. Working Papers in Sasak, vol. 1. Melbourne: Department of Linguistics \& Applied Linguistics, The University of Melbourne.

Marrison, G.E.

1999a Catalogue of Javanese and Sasak Texts. Leiden: KITLV Press.

1999b Sasak and Javanese Literature of Lombok. Leiden: KITLV Press.

Meij, Dick van der

1996a Nabi Aparas; The Shaving of the Prophet Muhammad's Hair. A Facsimile edition of a Javanese manuscript from Lombok, MS M.53 in the private collection of Dick van der Meij. With an introduction, transliteration and translation by Dick van der Meij, Leiden: ILDEP and Legatum Warnerianum Leiden University Library.

1996b 'Outpost of Traditions: The Island of Loambok', in: Ann Kumar and John H. McGlynn (eds) Illuminations; The Writing Traditions of Indonesia. Jakarta: The Lontar Foundation/New York and Tokyo: Weatherhill Inc. pp. 155-160.

Meij, Th.C. van der

2002 Puspakrema; A Javanese Romance from Lombok. Leiden: Research School of Asian, African, and Amerindian Studies.

Teeuw, A.

1954 'Balische invloed op het Sasaks', Bijdragen tot de Taal, Land-en Volkenkunde 110, pp. 116-31.

1958 Lombok. Een dialect-geografische studie. 's-Gravenhage: Martinus Nijhoff.

Uhlenbeck, E.M.

1978 'The Krama-Ngoko Opposition, Its Place in the Javanese Language System', in: Studies in Javanese Morphology. The Hague: Martinus Nijhoff (KITLV Translation Series 19), pp. 278-99. 


\section{Appendix 1}

\section{The manuscripts}

For convenience sake, the manuscripts have been designated A - C. They may be described as follows:

A. MS M.53 Palm-leaf (lontar) manuscript, $9 \mathrm{~cm}$ (width), 3,3 cm (height) and 3.3 $\mathrm{cm}$ thick (leaves and boards) or $2.1 \mathrm{~cm}$ (leaves). 44 leaves. 4 lines, jejawen script. Page numbers provided throughout on the b-sides of the leaves 1-39. The text runs from $1 \mathrm{~b}$ to $39 \mathrm{a}$. $39 \mathrm{~b}$ only has the page number 39 . The rest of the leaves contain no text. ${ }^{27}$
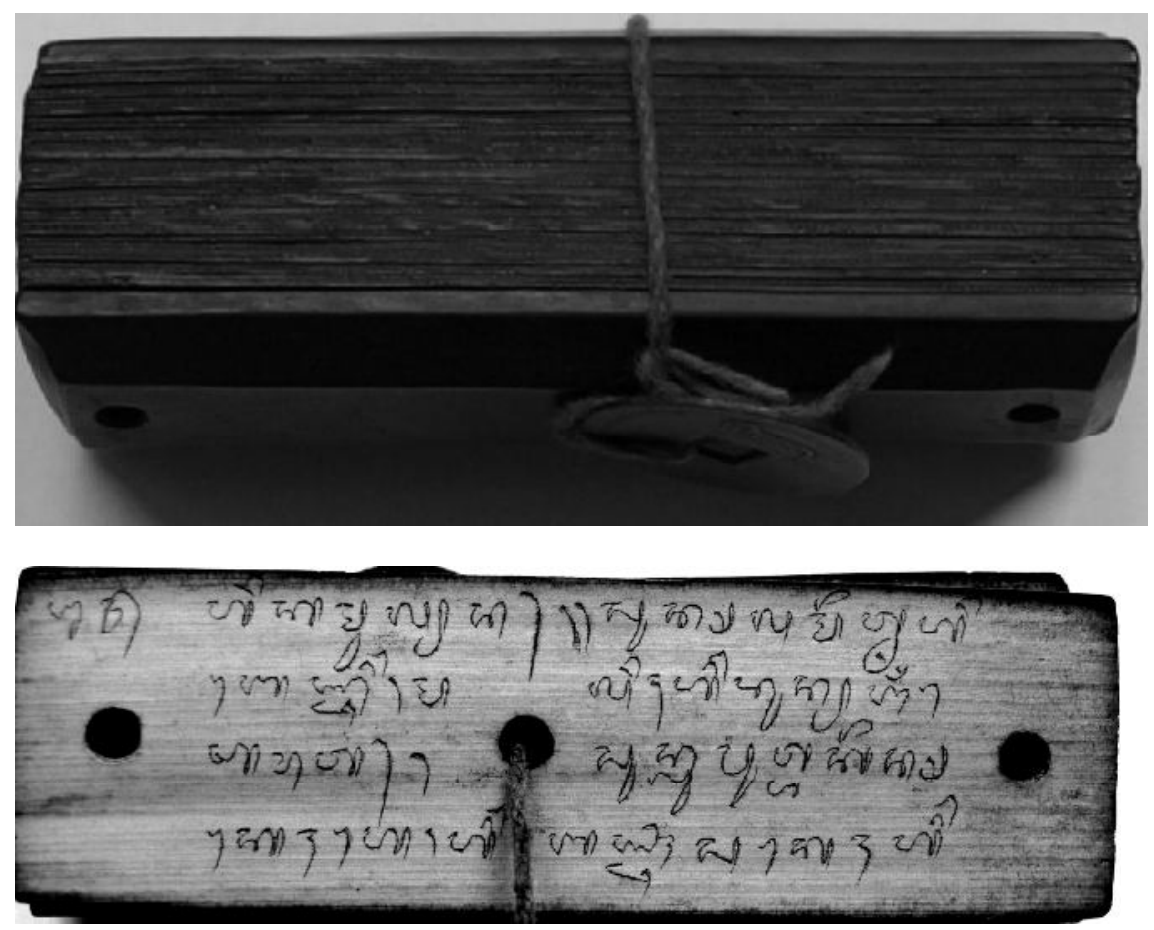

Ms. A, leaf 25b. 
B. MS M.64. Palm-leaf (lontar) manuscript, $13 \mathrm{~cm}$ (width), $2,8 \mathrm{~cm}$ (height) and 1.7 $\mathrm{cm}$ thick (leaves and boards) or $1.2 \mathrm{~cm}$ (leaves). 24 leaves. 4 lines, jejawen script. No page numbers. Leaf $1 \mathrm{a}$ has no text. The text runs from [1b] to [21a]. [23b] and [24a] have text in Arabic script which is very rare in lontar manuscripts; [24b] has no text.
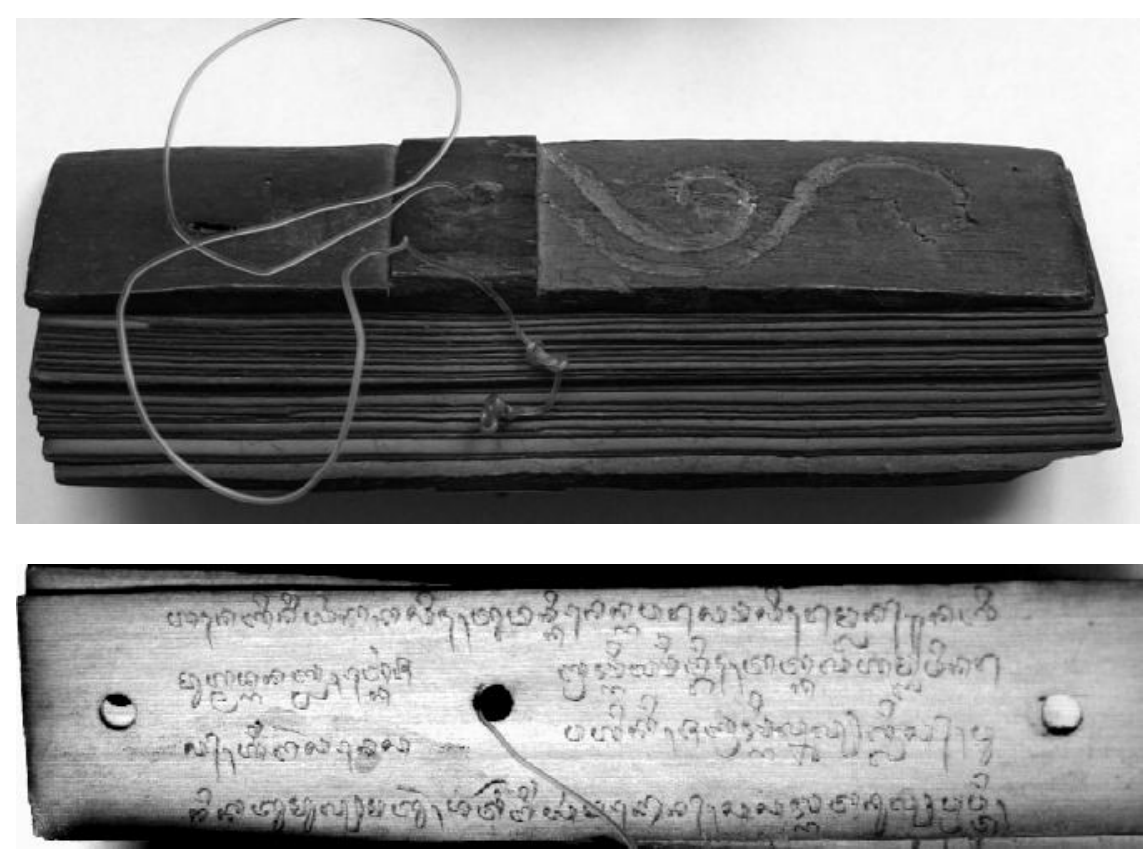

Ms. B, leaf 9a.

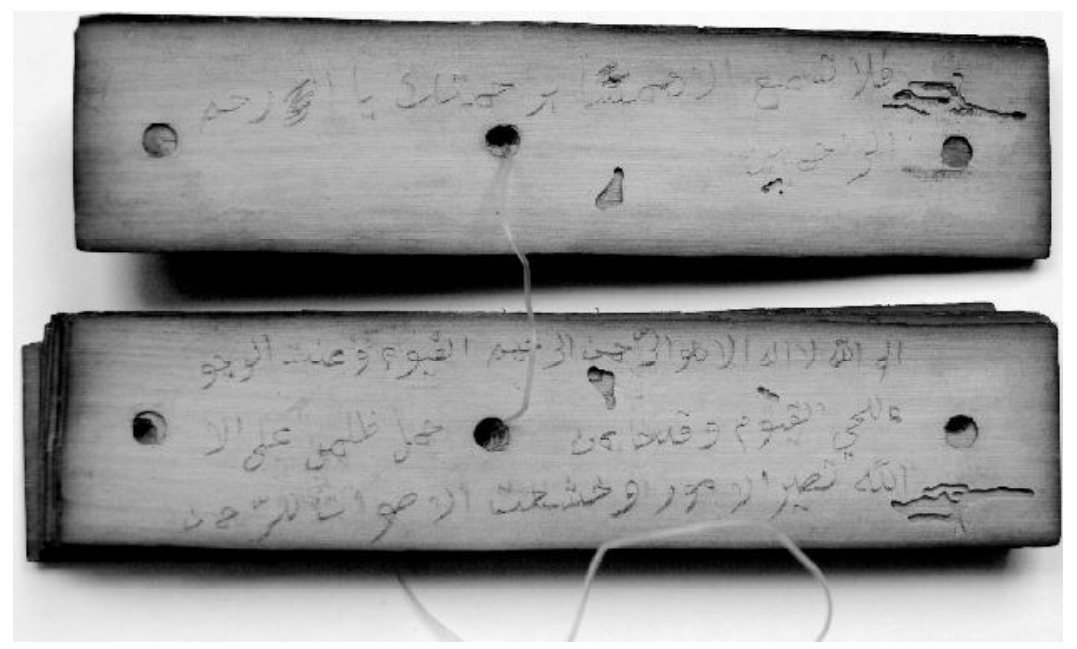

Ms B, leaves $23 \mathrm{~b}$ and $24 \mathrm{a}$ 
C. MS M.65. Palm-leaf (lontar) manuscript, $11 \mathrm{~cm}$ (width), $2.9 \mathrm{~cm}$ (height), and 6.4 $\mathrm{cm}$ thick (leaves and boards) or $3.9 \mathrm{~cm}$ (leaves). 44 leaves. 4 lines, jejawen script. Page numbers provided throughout on the b-sides of the leaves 1-69. The text runs from $1 \mathrm{a}$ to $69 \mathrm{a}$. $69 \mathrm{~b}$ only has the page number 69 . The text is preceded by two leaves without any writing.
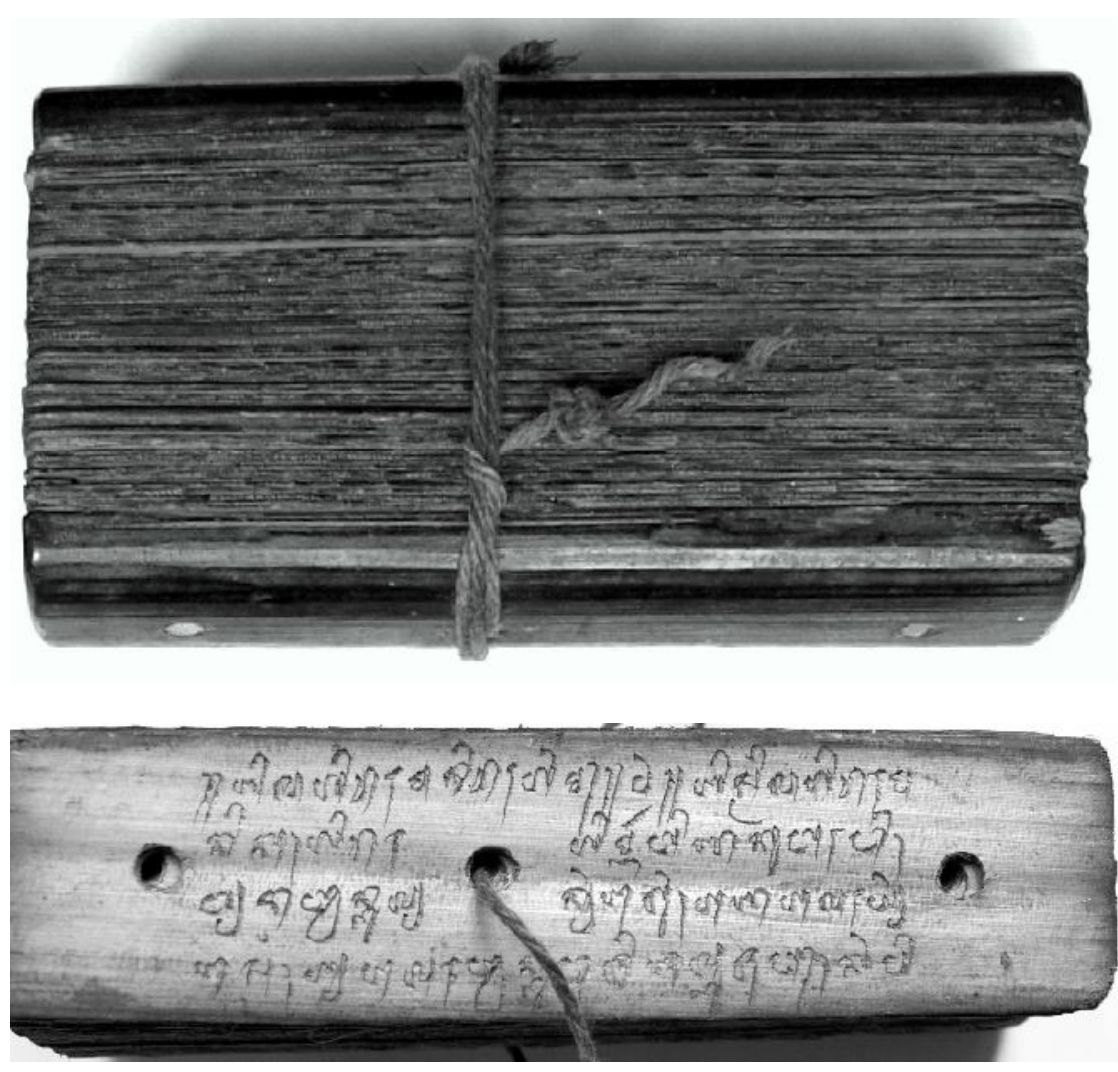

Ms. C, leaf 1a 


\section{Appendix 2}

\section{Translation of Manuscript C}

Bismillahirrahmanirrahim.

Pangkur

a. Bismillahirrahmanirrahim means that I acknowledge that there is no Lord but The Great One. Only Allah is benevolent, Allah is nguwajibalngujat, ${ }^{28}$ who is praised and to whom is paid homage day and night.

b. asah ajuh ya lailahra ilalla h means, I acknowledge that Allah is Great and that only Allah is Powerful among all that exists. He awards gifts and knowledge (???).

c. wah asal aduh and that Muhammad is Allah's messenger, which means that I acknowledge that the Prophet Muhammad is the true messenger of The Immaterial One who will judge everybody's true faith in Islam.

d. verily, with the intercession of the Prophet Messenger you will receive the gift of Heaven and people who repudiate are infidels.

1. Now will be told the story of the Prophet wali ${ }^{29}$ when his hair was shaved. A person came to Abu Bakar and asked, 'Under what circumstances

2. was the exalted Prophet's hair shaved? I ask you about Allah's Prophet, who was it who shaved his hair? And who witnessed the shaving of the Prophet's hair, and what was his head cloth and where did it come from?

3. And in what year was it, and on what date, and in what month? And how many strands of hair did he have?

Now, please tell me.' His majesty Abu Bakar said, 'The exalted Prophet's hair was shaved

4. while he was waging war on Allah's road. He was shaved in the village of Mecca, on a Monday.' While the Prophet Messenger was reading the Koran, ${ }^{30}$ Jabrail arrived, bringing a Koranic verse from Allah.

5. 'Well Prophet of The Immaterial One, I have come to you, sent as I am by The Great One, and I bring you a gift from The Highest which I am to convey to you, beloved Prophet.

6. These are the words of the Immaterial One and they are written in this letter. ${ }^{31}$ The fact of the matter is that you are ordered to have your hair shaved.' The Prophet Muhammad said to Jabrail, 'Well my brother,

7. who is to shave me?' Jabrail said softly, 'I will convey your question to The Great One.' Then Jabrail left to ask The Highest. He was not long underway, and in the wink of an eye he had arrived

8. in front of The Immaterial One. He asked The All Highest, 'My Lord, in what month is your beloved to be shaved, and who is to shave him?' The Immaterial One said, 'He is to be shaved in the month of Ramadan

9. and you will shave his hair.' Jabrail quickly went on his way and presently said to the Prophet Muhammad, 'Well Prophet of God, you are now ordered to have your hair shaved in the month Ramadan. The Prophet Muhammad said softly, 
10. to Jabrail, 'In front of whom will I be shaved?' Jabrail went to convey his message, and in the wink of an eye he had arrived

11. and in a short while, he came before the Prophet Messenger. Jabrail said to the Prophet Muhammad, 'You will be shaved in front of Nurcahya, because only you alone will know his name. ${ }^{32}$

12. No other than you will know. Thus is the order spoken by The One Who Leads.' 'Well, Jabrail what will my head cloth be after I have been shaved?' Then Jabrail left to ask The All Highest.

13. Having arrived before God, Jabrail said, 'Well my Lord, Great One, I would like to ask you, what will be the head cloth of your beloved when the exalted Prophet Muhammad's hair has been shaved?'

Sinom

14. The Immaterial One spoke to Jabrail, 'Leave at once and enter Heaven and pick one leaf of the Kastuba tree. ${ }^{33}$ Go now and fetch it at once. You will need only one leaf to make a head cloth ${ }^{34}$

15. and it is My gift.' Jabrail left immediately to pick a Kastuba leaf. He took one and it had a beautiful color because there is nothing that can match the color of the tree, nothing is like it. He quickly took it with him and in a short while he arrived at the Prophet Messenger.

16. When he had greeted him, (he said), 'Well Prophet, my Lord, this is a Kastuba leaf. This is what you will wear when your hair has been shaved. I will turn it into a head cloth by order of the Immaterial One, and it is a gift from Heaven, from Allah to you.'

17. The Prophet Muhammad said to Jabrail, 'Who will shave me?' Jabrail said kindly, 'The One Who Leads has ordered me to shave you. I have come to you, sent by The All Highest.' Then without any delay, the Prophet Muhammad was shaved.

18. The time of the shaving of the Prophet's hair by Jabrail was on the $19^{\text {th }}$ of the month Ramadan, on a Monday. Afterwards they prayed two sequences of prayers (raka'at). Thus was the shaving of the Prophet, to the satisfaction of all who witnessed it.

19. Each strand of hair was taken up and none fell on the ground. The Prophet said to Jabrail, 'Why is it that really of all my hair, none falls on the ground? Jabrail said kindly, 'Well Muhammad my Lord.

20. The reason that they do not fall on the ground is that for all the number of your hair there is an equal number of nymphs to catch them (before they reach the ground). 'The Prophet said kindly, 'How many hairs do I have? Jabrail said, 'You have much hair, no more than three hundred thirty three thousand,

21. three hundred thirty-three in total. Now each hair will be used by a nymph and none will fall on the ground. The reason your hair is being fought over is, that Allah has ordered the nymphs to do so. That was the order of the Lord the Most Sublime. 
22. The order of Lord the Most Sublime to the nymphs was, 'Go and leave at once and go to my beloved. All of you have to go and catch one hair and turn each hair of My Beloved into a charm, and each of you put one on your wrist.

23. So that all of you I will safeguard from illness and from the fire of Hell. I will protect from illness whoever owns this story of the shaving of my beloved's hair and anyone willing to preserve it.'

Smaradana

A. 'I will keep him away from illness and later, when he is in death's throws and his spirit has been set free I will intercede on his behalf. And whoever reads it, and whoever listens to the story of the shaving of the Prophet

B. and whoever writes it down or who owns it or otherwise keeps it, and whoever carries the story of shaving of My Beloved with him, I will give him distinction.

C. I will protect him for the duration he is on earth and after death until eternity. I will liberate him later from all torments and from the Angels of Death, Munkar and Nakir, and from all the agonies of the grave and from those of the Day of Judgment.

D. And I will never let him out of My eyes and I will forever have mercy on him and I will keep him far from disaster and from the Devil and the evil spirits. But, he who does not keep this story and who does not wish to read it (and who do not wish to read it),

E. and who does not believe what it tells, and who refuses to listen to it, surely fakes his faith, and I will be very displeased with him. However, he who pays close attention to it, I will make happy and I will keep him far from misery.

F. I will safeguard everything in the house of him who keeps this story and preserves it in his house and I will protect the house and keep all living creatures in it far from danger and fire will be extinguished by water.

G. Take the story along when you go out to the poor and needy when you give your alms to them. I will reward you however much you give to those poor and needy.

$\mathrm{H}$. If you were to give just a tiny bit, I will repay you seventy thousand times. Where it will come from? From the Almight y of The Immaterial One.' Thus spoke Allah who bestows his wonderful gifts, all of the highest quality. ${ }^{35}$

I. The Prophet will intercede both on behalf of those who give and on those who receive. What is given and what is received are equal divine favors (what is given and what is received). The Prophet Messenger said, 'Bear my words in mind and believe the

J. story of the shaving of the Prophet's hair. When you copy it you will obtain God's mercy for one day, wealth and poverty may come every day without end and blessing will come uninterrupted.

K. It will protect ${ }^{36}$ you from all sorts of danger and from all criminals and I will protect you from losing your way. When you are ill, you will swiftly be helped and the magic of sorcerers will be harmless. 
L. When you make this charm against dangers, every kind of evil spirits and all savage animals will all be scared. If you take the story of the shaving of the Prophet's hair to the sea

M. the fish in the sea, ferocious fish will disappear and all will be terrified and will not dare approach you and when you set sail, you will presently arrive where you want to go because of the beneficial influence of the story.

$\mathrm{N}$. When you take it along when set out for war, all weapons, firearms, lances, swords, and spears will vanish, and your fighting will be valiant, / because of the great gift of The Great One / which the story carries.

O. If you have a job to do or something needs to be produced, it will quickly be done. You will find happiness and many will be sympathetic to you and you will not be struck by the wrath of a king and will not be a pitiable servitor.

P. And later, after you have died you will not lose your way on the road but yours will be a martyr's death. Those who carry the story of the shaving of the Prophet's hair will obtain the beloved Prophet Muhammad's unrivalled benefaction

Q. and additional blessings of the Prophet, / the beloved Messenger of Allah. / Whoever does not believe / but has doubt in his heart, / and he does not believe / that person will really / find himself on an ill-fated road. 


\section{Endnotes}

1. On these two variant of Islam in Lombok see, for instance, Budiwanti 2000.

2. The only detailed expositions of literature among the Sasak are Marrison 1999a and 1999b. For an expose of the use of texts and manuscripts during rituals in Lombok see Van der Meij 1996b and 2002:181ff.

3. Many manuscripts have been transliterated in a variety of Indonesian State sponsored projects. A bibliography of these publications may be found in Van der Meij 2002, pp. 227-230. The only two English language editions of texts from the Sasak area so far are the Nabi Aparas (Van der Meij 1996) and the Puspakréma (Van der Meij 2002). Van Eerde published Dutch translations of the Sasak Tutur Monyè (1906) and the Tutur Cilinaya (1913) while Behrend (1987) paid attention to the Serat Jatiswara from Lombok, unfortunately without presenting an edition.

4. The manuscripts are part of the private collection of the author. Descriptions and photographs follow in appendix 1.

5. Two of the three lontars also add some other text, which we will ignore here.

6. A study on the colophons found in Sasak manuscripts is highly desirable as it may shed light on ideas of time designation. If colophons are found they usually only mention that a manuscript was borrowed from so and so and the writing was finished in Ramadan while sitting in front of the mosque, or some such. Any clear reference to a checkable date is mostly absent.

7. Other texts that follow in the manuscripts have been ignored here. In the transliterations, A and B have been presented before C simply because they show many correspondences, but I might just as well have started with $\mathrm{C}$. There is therefore no apparent reason to present the texts the way I did and no conclusions should be attached to this sequence.

8. I hesitate to use the word 'mistake' because in this kind of fluent text tradition it is hard to establish whether a difference is indeed a mistake or a purposeful variation. What I mean with a mistake is a clear misinterpretation of a Javanese character by the copyist, or pieces of text that have no meaning and cannot but be indicative of an error of some sort by the scribe.

9. See Teeuw, 1958 and Jacq, 1998.

10. Interview with Lalu Gede Suparman and I Nyoman Argawa, Ampenan, April 1995.

11. On the krama-ngoko opposition, see e.g. Uhlenbeck 1978. 
12. The Sasak have a long history of wars and cultural contacts with the Balinese and a sizable population of Balinese live in the western part of Lombok. On the influence of Balinese on Sasak see Teeuw, 1954.

13. Macapat texts are meant to be sung but since we are concerned here with textual study based on manuscripts, the performing in $s$ and outs are ignored here.

14. For more information on these meters and macapat in Lombok see Van der Meij, 2002, pp. 170-173.

15. The numerals indicate the number of syllables per verse line and the letter indicates the vowel in the last syllable of the line.

16. Apparently, the number of syllables in the meters as used by the Sasak is less than their theoretical number. 'Theoretically', sinom should have 74 syllables per stanza. The total number of syllables for the 20 stanzas of A should therefore be 1480 but is only 1453 , B has 1378 rather than 1406 for its 19 stanzas while $\mathrm{C}$ for its 10 stanzas has 724 rather than 740 . Pangkur in $\mathrm{C}$ also has a shortage of syllables. One stanza theoretically has 62 syllables and therefore the total pangkur material in C for 13 stanzas should be 806 syllables. With the correction for the missing line 5 in stanza 10 (theoretically 12 syllables) the total number is only 794 and therefore has an average of 61 .

17. One stanza has been omitted here.

18. If all these differences were acknowledged in an apparatus criticus, it would probably be more extensive than the text itself.

19. For choices for synonyms because of metri causa reasons, see table 4 below.

20. Note the regular occurrence of the verb paras in lines 3 and 9 in many stanzas in A and B. Total verb correspondence (12 out of $27=46,1 \%$ ) is indicated in bold. A and B show 84,6\% correspondence, A-C 46,1 and B-C $50 \%$.

21. Carey 2008:156.

22. Carey 2008:156.

23. Carey 2008:156.

24. Ignoring differences in spelling (yang/hyang), the total correspondence is $15,3 \%$ (4 out of 26 ). A and B show $65,3 \%$ correspondence, A-C 26,9 and B-C also $26,9 \%$.

25. The total correspondence between the three manuscripts is $64,2 \%$ (9 out of 14). Correspondence between A and B is $85,7 \%$, between $A$ and $C$ $57,1 \%$, and between $\mathrm{B}$ and $\mathrm{C} 78,5 \%$. 
26. The total correspondence between all three manuscripts is $53,8 \%$ (42 out of 78). Correspondence between $\mathrm{A}$ and $\mathrm{B}$ is $83,3 \%$, between $\mathrm{A}$ and $\mathrm{C}$ $52,5 \%$ and between B and C 56,4\%. In its use or omission, $39.7 \%$ of the verbs in manuscript $\mathrm{C}$ are totally different from the two others.

27. This manuscript has been described in 1996 with the text, a translation and a facsimile of the entire manuscript (Van der Meij 1996)

28. The spelling of the Javanese script makes it hard to understand this and the following expressions which are in Arabic but we have been unable to identify.

29. Muhammahd is usually called the rasul, 'messenger'. But here he is called a wali, 'early apostle or saint of Islam in Java; the wali are usually said to have been nine in number' (Carey 2008:844)

30. A wonderful inconsistency with Islamic history. Muhammad could not have possibly been reading the Qur'an as it had not yet been committed to paper.

31. In the Indonesian context, the word surat may also indicate a chapter of the Koran but that is probably not what is meant here.

32. This is not altogether clear to me.

33. See the comment under paragraph 4. Line sequence.

34. I presume Jabrail makes the head cloth but this is my interpretation, as it remains unclear from the story.

35. It is interesting to read that Allah directly addresses the faithful apparently without Muhammad's mediation.

36. The text has rinaspa, which does not exist. As Ms A has rinaksa I assume Ms $\mathrm{C}$ has a mistake.

Dick van der Meij is affliated with PPIM and CSRC, UIN Jakarta 